\title{
17. Yüzyılın Sonunda Bir Safevî Elçisinin Osmanlı Devleti'ne Maliyeti
}

\author{
Reyhan Şahin Allahverdi*
}

\section{$\ddot{O} z$}

Osmanlı diplomasisine dair olan çalışmamız 1696 yılı sonunda II. Mustafa'nın cülusunu tebrik münasebetiyle İran'dan gönderilen ve İstanbul yerine Edirne'de ağırlanan Horasan Hakimi Ebu'l-Ma'sum Han'ın elçiliğini kapsamaktadır. Dolayısıyla elçinin tayininden itibaren doğu sınırında başlayıp geri dönüşte yine aynı yerde biten diplomasi süreciyle söz konusu elçinin Osmanlı Devleti topraklarında bulunduğu zaman diliminde devletin kendisi için verdiği "tayinat" masrafi ele alınmıştır: İran elçisinin yolculuğunda karşılama, eşlik etme, İstanbul'a gelinceye kadar elçinin ve hizmetinde bulunan maiyetinin yol güvenliğinin sağlanması, konaklama işlerinin düzenlenmesi, İstanbul'a ulaştıktan sonra Anadolu yakasından (Üsküdar), Sarayburnu'na geçirilmesi, sultanın Edirne'de bulunması sebebiyle oraya götürülmesi ve Divan-1 Hümayun'a kabul edilinceye kadar ikamet edecekleri yerlerin donatılmasi, Divan'a kabulleri sirasında ve sonrasında tatbik edilen teşrifat ve elçilik heyeti için yapılan harcama (tayinat) kalemleri değerlendirilmiştir. Bu dönemde II. Viyana Kuşatması'ndan sonra başlayan Batı cephesindeki uzun savaşın kötü gidişatına bağlı olarak İran'la mevcut barış halinin devamının sağlanması Osmanlı hükümeti açısından son derece önemlidir. Bu nedenle, Osmanlı arşiv kaynaklarına dayanan bu çalışmayla elde edilecek bulguların İran'la olan elçi teatilerinin önemini göstermeye katkı sağlaması umulmaktadır. Diğer bir ifadeyle, elçilik heyeti için yapılan harcamalar üzerinden İran'a atfedilen stratejik ve diplomatik önem analiz edilmiştir. Keza, Osmanlı Devleti'nin Ebu'l-Masum Han'dan önce ve sonra gelen İran elçilerine karşı takip ettiği klasik elçi ağırlama usulleriyle karşılaş̧ırıldığında, teşrifat benzerdir. Merasim ve teşrifatta eski kaidelere riayet edilmekle beraber Osmanlı Devleti'nin Avusturya ve müttefikleriyle savaşta olmasından dolayı elçi nezdinde İran'a karşı bir hayli dostluk ve büyük bir debdebe gösterildiğine dair bulgular elde edilmiştir. Yine elçinin misafir edilmesi ve huzura kabulü sırasında yapılan merasimlerin İstanbul ve saray dışında gerçekleşmesinin bazı farklı yanları bulunmaktadır. Bunlar ve ilave çıkarımlar için başta döneme dair arşiv evraklar ile çağdaş Osmanlı kronikleri ve bazı araştırmalar kullanılmıştır.

Anahtar Kelimeler: İran, Osmanlı İmparatorluğu, Diplomasi, Safevî Elçileri, Tayinat Sistemi.

Doç. Dr., Burdur Mehmet Akif Ersoy Üniversitesi, Fen-Edebiyat Fakültesi, Tarih Bölümü, Burdur, Türkiye, reysahverdi@mehmetakif.edu.tr, ORCID: 0000-0002$5147-4412$ 


\title{
The Cost of a Safavid Envoy to the Ottoman Empire at the End of the 17th Century
}

\author{
Reyhan Şahin Allahverdi*
}

\begin{abstract}
This paper on Ottoman diplomacy includes the envoy Abu'l-Ma'sum Khan the ruler of Khorasan, who was sent from Iran to congratulate the enthronement of Sultan Mustafa II at the end of 1696 and was hosted in Edirne instead of Istanbul. Therefore, the diplomatic process beginning at the eastern border following the envoy's appointment and ending at the same point on his return, and the "rations" allotted by the government during the accommodation of the envoy were discussed. The welcoming of the Iranian envoy during his travel, accompanying him on his journey to Istanbul, ensuring the safety of the road for him and his entourage as he journeyed to Istanbul; after reaching Istanbul, his crossing from the Anatolian side (Uskudar) to Sarayburnu; his taking to Edirne as the Sultan was there and equipping the places where they would reside until the envoy had an audience before the Imperial Divan; the honours and expenses (allotment/ tayinat) made for the delegation during and after their admission to the Court were tried to be evaluated. It was extremely important during that time for the Ottoman government to ensure the continuation of the current peace with Iran, depending on the bad course of the long war on the Western front, which started after the Second Siege of Vienna. Hence, it is hoped that the findings to be obtained through this study, which is based on Ottoman archival sources, will contribute showing the importance of envoy exchanges with Iran. In other words, the strategic and diplomatic importance attributed to Iran through the expenditures made for the delegation was analyzed. Likewise, the ceremony is similar when compared with the classical methods of hosting the envoys of the Ottoman Empire against the Iranian envoys who came before and after Ebu'l-Ma'sum Khan. Although classical rules were followed in ceremonies, it became clear that as the Empire was at war with Austria and its allies, a great deal of friendship and pomposity was shown to Iran in the envoy's presence. Again, the ceremonies held during the accommodation and reception of the envoy have some different aspects as they all took place outside of Istanbul and the palace. For these and additional inferences the archival documents of the period, contemporary Ottoman chronicles, and some researches have been employed.
\end{abstract}

Keywords: Iran, Ottoman Empire, Diplomacy, Safavid Envoys, Tayinat System.

Assoc. Prof., Burdur Mehmet Akif Ersoy University, Faculty of Science and Literature, History Department, Burdur, Turkey, reysahverdi@mehmetakif.edu.tr, ORCID: 00000002-5147-4412 


\section{Giriş}

16. yüzyılın başında İran'da Safevî Devleti'nin kurulmasından itibaren Osmanlı Devleti ile Safevî hanedanı arasında yaklaşık 250 yıl devam edecek olan ilişkiler başladı. Osmanlı-Safevî diplomasisi başlangıçta, özellikle Osmanlı'nın doğu sınırında büyük bir tehdit unsuru olarak bulunmasının yanı sıra dini/sosyal ve ekonomik sebeplerle çıkan savaşların öncesi ve sonrasındaki mektup teatileriyle yürütülüyordu. Savaşın taraflardan birinin lehine dönmesiyle özellikle zor durumda olan devlet temsilcileri sulha meyletmeye başlıyordu. İlk iletişim seferde olan padişah / serdarların temsilcilerinin karşılıklı ordugâha gidip gelmesiyle sağlanırdı. Karşı tarafın durumunu tahkik için kullanılan casusların sözlü raporları da dikkate al1narak görüşmeler derinleştirilirdi ve iki taraf da karşılıklı elçilik heyetleri tayin ederlerdi (İskender Bey Münşî, 2019, s. 43, 110, 177-185). Taraflar arası yazışmaların suretleri, Name-i Hümayun defterlerinde kayıtlıdır (M.S. Kütükoğlu, 1994, s. 145-161).

Osmanlı Devleti'ne gelen elçilerin İstanbul'da ağırlanması adettendi. Bu çalışmada ise cülus tebriki için gelen Safevî elçisine İstanbul dışında, Edirne'de uygulanan teşrifat ile elçi ve heyeti için yapılan harcama kalemleri incelenmiştir. Elçi İran'dan gelmiş olsa dahi o tarihteki geliş amacına ve iki ülke arasındaki ilişkilerin durumuna göre gösterilen muamele ve verilen hediyelerde farklılık olmaktadır. Bunun en önemli örneklerinden biri, Ebu'l-Ma'sum Han'in II. Mustafa'nın tahta cülusu münasebetiyle İran Şahı adına cülus tebrikine gelişinde yaşanmıştır. Zira Osmanlı'nın Batı cephesinde varoluş mücadelesi verdiği bir dönemde, İran'la ilişkiler hayati önem arz etmektedir.

Ağırlama hizmetleri ve tayinat ödeneğinin yanısıra iki sultanın karşılıklı hediyeleşmesi de yine devrin diplomasisinin bir parçasıydı. Muhatap devletle ilişkilerin muhtevasına ve Şah'tan gelen hediyelerin kıymeti derecesinde hatta daha pahalı hediyelerle mukabele edilirdi.

Bu bağlamda, II. Viyana kuşatmasının (1683) başarısız sonuçlanmasından itibaren Osmanlı Devleti'nin Avusturya ile başlayan ve süren savaş hali doğuda Safevî Devleti ile olan diplomatik ilişkileri ne şekilde etkilemiştir? Osmanlı idaresi Avusturya cephesindeki kötü gidişatın bir sonucu olarak mı İran'dan gelen elçi Ebu'l-Ma'sum Han'ın ağırlanmasında bu derece ihtimam göstermektedir, yoksa İran elçisine gösterilen dostane muame- 
le zaten klasik Osmanlı diplomasi anlayışının bir sonucu mudur? Ebu'lMa'sum Han'ın elçiliğinin Osmanlı idaresi nazarındaki yerini anlamak adına, ondan kısa bir süre sonra, Basra meselesi nedeniyle gerilen ilişkileri düzeltmek üzere, Safevî Şahı adına gelen Rüstem Han'ın ağırlanması ve bu misafirliğin masrafları ile Ebu'l-Ma'sum Han'a yapılan harcamalar arasında ne gibi farklar vardır? Daha genel bir ifadeyle, İran'dan gelen elçilerin Osmanlı Devleti tarafindan kabulü, ağırlanması ve yapılan harcamalar Safevî Devleti ile ilişkilerin gidişatına bağlı olarak farklılık gösteriyor muydu? Çalışmanın problematiği bu sorular üzerine inşa olunmuştur.

Bu çalışmada Ebu'l-Ma'sum Han'ın başkent dışında Edirne Sarayı'nda huzura kabul edilişi ele alınmaktadır. Zira II. Mustafa saltanatı boyunca sefer harici zamanlarda dahi Edirne'de uzun zamanlar geçiren padişahlardan biriydi (Sevinç, 2012). Edirne'de elçilik heyetinin misafirliği boyunca başkent İstanbul'da İran elçileri için geçerli olan teamüllerin uygulanıp uygulanmadığg tespit edilmiş; elçi ve maiyetinin yeme-içme, yolculuk ve ikametleri için hazırlanan yerlerin mefruşat giderlerinin; ilaveten elçiye ve heyetine sunulan ihsanlarla (yol harçlığı, hediye vb.) Şah'a gönderilecek hediyelerin, devlet hazinesine maliyeti ele alınmıştır.

Daha önce Osmanlı diplomasi tarihi üzerine yapılan araştırmalardan kısaca bahsedilecek olursa, genel olarak bunlarda iki devlet arasındaki askerî siyasî ilişkiler ve/veya barış antlaşmaları ele alınırken bazı araştırmacılar Osmanlı Devleti ile münasebetleri devam edegelen devletlerden gelen elçiler ve faaliyetleri konusuna yoğunlaşmaktadır. Bunlara ilaveten Osmanlı devletinin Avrupa'ya geçici veya kalıcı olarak ikamete elçi tayin etmeye başlamasından itibaren sefirlerin yazdığı sefaretnameler (Korkut, 2003, s. 491-511) ile yabancı devlet kralları yahut sultanlarıla yapılan yazışmalarının suretlerinin kaydedildiği Name-i Hümayun Defterleri gibi birincil kaynakları ele alan bazı kitap, tez çalışması ve makale mevcuttur.

Osmanlı Devleti ile Safevî Devleti arasındaki “münasebetler” hakkında yapılan çalışmalar daha ziyade siyasi ve askeri meselelerle alakalıdır. Bunlar da belli bir yüzyıl savaş, barış yahut kişi özelinde kaleme alınan son derece kıymetli monografik çalışmalardır. 1721'de bir yıllığına sefir olarak İran'a gönderilen ve bir de sefaretname yazan Dürri Mehmed Efendi'ye kadar 16. ve 17. yüzyıllarda yürütülen elçilik hizmetleri ve elçilerin ağırlanması konusunda mevcut literatürden bazıların zikretmek yerinde olacaktır. Bu minvalde ilk çalışma, Şerafettin Turan’ın (1964) “1560 Tarihinde Anadolu'da 
Yiyecek Maddeleri Fiyatlarını Gösteren İran Elçilik Heyeti Masraf Defteri” adlı makalesidir. Bekir Kütükoğlu'nun (1994) da Şah Tahmasb'ın III. Murad'ın tahta çıkışı münasebetiyle gönderdiği elçi Tokmak Han'a dair bir makalesi bulunmaktadır. Yine 16. yüzyılda, Osmanlı Devleti'yle İran arasında yürütülen diplomasi Reyhan Şahin Allahverdi'nin (2019) kaleme aldığı "İsmiyle Yaşayanlar: Siyavuş Paşa ve Vakıfları" adlı eserde bir k1sım olarak yer almaktadır. Özellikle ele aldığımız Şah Hüseyin döneminde İran' dan gelen elçilerin ağırlanması ve tayinatlarıyla ilgili müstakil bir yüksek lisans tezi de Nurten Sevinç (2012) tarafından hazırlanmıştır. İran'dan gelen Ebu'l-Ma'sum Han ve Rüstem Han'ın elçiliklerinin akabinde mütekabiliyet maksadıyla İran Şahı'na gönderilen Defter Emini Mehmed'in Osmanlı coğrafyasından çıkıncaya kadarki tayinat ve yol masraflarıyla ilgili bir çalışma da Uğur Kurtaran (2019) tarafından kaleme alınmıştır. İran tarafında ise İskender Bey Münşî’nin (2019) yeniden yayımlanan “Tarih-i âlem-Ârâ-yı Abbâsî” adlı çağdaş eserinde 17. yüzyılda Osmanlı Devleti ile İran arasında yaşanan savaşlar ve her iki ülkenin diplomatik faaliyetlerini yürüten elçilerle ilgili ayrıntılı bilgi bulunmaktadır.

Osmanlı diplomasisi alanında yapılan çalışmalarda özellikle elçilerin ağırlanması sırasında ve sonrasında devletin harcama kalemlerini gösteren kayıtların incelenmesi son derece önemlidir. Bu evraklara arasında en detaylı bilgi tayinat defterleriyle hazineden verilen tezkire ve temessüklerde bulunmaktadır. Devlet elçilik masrafları için ödemesi gereken parayı her zaman nakit olarak yapmıyor, tahsisat usulünü kullanıyordu (Başbakan11k Osmanlı Arşivleri [BOA] Ali Emiri Sultan Mustafa II, [AE.SMST.II], 40/3914, 5 Receb 1108/28 Ocak 1697). Bu bakımdan tahsisatın yapıldığ kaynağın incelenmesi sırasında devletin ekonomik-mali yapısına dair bilgi toplama imkânı olduğu gibi bölgesel tarihe dair malzemeden de yararlanılmaktadır. Bu kayıtların araştırılması sadece devletin masraflarını değil devrin fiyat (narh) politikalarını (Turan, 1964, s. 273-294) ile dönemler arasındaki fiyat değişimini (enflasyon) anlamak bakımından da dikkate değerdir.

Elçi masraflarının incelenmesinde merkez bürokrasiye ait evrakın yanında elçiye yapılan tahsisatların karşılandığı yerel idarenin (kadı sicilleri) kayıtları da son derece aydınlatıcı niteliktedir (Sak, 2009, s. 117-161). Bu tahsisatlar kadı aracılığıyla ilgili yerin mukataa ve vergi (nüzül, avarız vb.) kaynaklarından yapılmaktadır. 
$\mathrm{Bu}$ çalışma ise İran elçisi sıfatıyla Osmanlı Devleti'nde bir süre ikamet eden Ebu'l-Ma'sum Han ve heyetinin Osmanlı Devleti sınırlarında bulunduğu süre içinde devletin içinde bulunduğu savaş koşullarının elçiye gösterilen misafirperverliği olumlu veya olumsuz etkileyip etkilemediğine; yine bu durumun elçi ve adamlarına verilen tayinat ve hediyelerin değerine yansıyıp yansımadığı üzerine yoğunlaşmaktadır.

\section{Osmanlı Devleti'nde Elçi Kabulü Uygulamaları ve Tayinat Usulü}

Osmanlılar, devletin kuruluşundan itibaren gerek batıda Hıristiyan devletlerle gerek doğuda Müslüman beylikler ve devletlerle diplomatik ilişkiler kurmaya başlamışlardır. 14. ve 15. yüzyılda diplomasi karşılıklı elçiler ve mektuplar teatisiyle yürürdü. Osmanlı-Safevî ilişkilerinin başladığı 16 . yüzyılın diplomasi usulü "hususi elçiler"in karşılıklı iki taraf arasında belli bir amaca yönelik olarak gelip gitmesine dayanan, "ad hoc" diplomasisidir. (Arı, 2004, s. 36-65). Bu usulde devletlerin hükümdarlarının değişiminde cülus tebriki, ittifaklar veya barış görüşmelerinin yürütülmesi gibi sebeplerle karş11ıklı elçilerin gelip-gitmesi esastı (Uzunçarş111, 1988, s. 268-272). Bu türden elçilere; müstakil meseleler için gidip geldikleri için "fevkalade elçiler" denilmektedir (M. S. Kütükoğlu, 1989, s. 199). Sultan III. Selim devrinde 1793 y1lında elçilikte mütekabiliyet usulünün kabulüne kadar Osmanlı başka devletlerin başkentlerinde "mukim" elçiler bulundurmamıştır. Oysa ilk dönemlerden itibaren Venedik baylolarından başlamak üzere Avrupalı devletler İstanbul'da mukim elçiler bulundurmaya gayret etmişlerdir (Topaktaş, 2015, s. 33; Düzbakar, 2009, s. 186).

Osmanlı Devleti'nin Müslüman çağdaşı devletlerle olan diplomatik ilişkileri de yine batılı devletlerle olduğu gibi karşılıklı "hususi elçiler" vasıtasıyla; mektup ve hediye teatisiyle yürütülürdü. Bunlar içinde Şîi İran ile daima düşmanca ve savaş halinde bir ilişki mevcuttu. Buna karşın Sünni Hindistan sultanlıkları ve Fas Sultanlıkları ile, onların Osmanlı padişahı (halife) tarafından "himaye" edilmesi tarzında bir münasebet söz konusuydu (Uzunçarş111, 1988, s. 268-272).

Osmanlı tarafının Safevîlerle ilk temasları Şah İsmail tarafından Tebriz merkezli olarak devletini kurmasına kadar uzanmaktadır. 16. yüzyılın hemen başında Osmanlı'nın doğusunda ortaya çıkan İran'daki Şiî Safevî 
Devleti'yle Osmanlı Devleti'nin yakın coğrafyalarda bulunmaları sebebiyle aralarındaki savaşlar kaçınılmaz bir durumdu. Bu devletin doğuşu Osmanlı Sultanı II. Bayezid saltanatına denk gelmektedir. İlk Safevî elçisinin Şah İsmail tarafindan 1501 yılında (Unat, 2008, s. 243) Osmanlı Devleti'ne gönderildiği kabul edilmektedir. Osmanlı tarafından ise Şah İsmail Tebriz'de şahlığını ilan ettiğinde, Sultan II. Bayezid, 1505 kışında ona elçiler göndererek tebrik etmişti (Gündüz, 2005, s. 452; Gündüz, 2015, s. 82). 1514 yılındaki Çaldıran Savaşı öncesinde, savaşta ve sonrasında Sultan Selim ile Şah İsmail arasında karşılıklı mektupların taşınması için de yine karşıl1klı elçiler gelip gitmiş̧i (Gündüz, 2015, s. 123-128; Unat, 2008, s. 243). A. Yaşar Ocak'a göre (2002, s. 503) Osmanl1-Safevî münasebetleri, hanedanlar özelinde Safevî Devleti'nin 1501'de fiilen kuruluşundan daha eskiye gitmekle beraber 1501 'den sonra "devletlerarası" siyasi ilişkiler boyutunda devam eden "bir çatışmalar tarihidir".

İran savaşları; Sultan I. Selim ve ondan sonra Kanuni Sultan Süleyman döneminden itibaren Safevî hanedanının fiilen 1722 resmen 1736 yılındaki (Gündüz, 2005, s. 455) yıkılışına kadar aralıklarla devam etti. Dolayısıyla iki buçuk asır boyunca gerek cülus tebriki ve mektup teatisi gerekse barış müzakereleri münasebetiyle karşılıklı heyetler gönderildi. Bu elçilerin gelişi, konaklaması ve geri dönüşü esnasında uygulanan protokol ve elçinin masraflarının karşılanması belli kaideler çerçevesinde olurdu.

Elçi ve heyeti doğu sınırından Osmanlı topraklarına girdiği andan itibaren karşılanır ve Osmanlı yol sistemi dâhilinde mihmandarlar eşliğinde yolculuk ettirilirdi. Mihmandarın görevi, maiyetinde oldukları kişilerin Osmanlı topraklarına ayak bastıkları andan itibaren başlayıp ülke sınırlarını terk etmelerine kadar olan süreyle sinırlıdır (Can, 2019, s. 270-271). Elçiler; İstanbul'a, bazen de sultan seferde yahut kışlakta ise ilgili şehre götürülürdü (BOA, AE.SMST.II, 102/11060). Alman/Avusturya elçisi Busbecq Osmanlı-İran savaşları esnasında Amasya'da kışlakta bulunan Sultan Süleyman'la görüşebilmek için 1555'de Amasya'ya gitmek zorunda kalmıştır (Busbecq, 2014). Mihmandarlık uygulaması Safevîlerde de mevcut olup 1612'de İran'a gelen Özbek Hanı Muhammed Veli Han'ın mihmandarlık görevi, şahın Eşikağası Başı Şamlu Ali Kulu Han'a verilmişti (İskender Bey Münşî, 2019, s. 603).

$\mathrm{Bu}$ yolculuklar sırasında da yine elçinin ve yanındaki maiyetinin hatta ona eşlik eden Osmanlı memurlarının masrafları "tayinat" uygulaması (To- 
paktaş, 2015, 31-49) dâhilinde devlet tarafından karşılanırdı. Bu maliyetin karşılanması, çoğunlukla elçinin geçeceği güzergâhtaki halkın vergilerinin masraflara tahsisi şeklinde olurdu. Bazen de onlara yollarda eşlik eden mihmandara önceden verilen bir para ile rayiç fiyat üzerinden mal ve hizmet satın alınması usulü takip edilirdi. İlgili güzergâhın yöneticilerine gönderilen emirlerle bu sistemin aksaması önlenmeye çalışılmaktayd 1 (Kütükoğlu M.S., 1989, s. 199-201).

Tayinat sistemi Osmanlı diplomasisinde başlangıçtan itibaren zamanla yerleşmiş bir kural olmakla birlikte ilk defa 1589 yılında Floransa adına İstanbul'a gelen Dük Kozma dö Medici'nin elçisine hazineden tayinat ödendiği kabul edilmektedir (Uzunçarşı11, 1988, s. 276). Avrupalı devletler de bu kaideye uymak ve mütekabiliyet esasına göre Osmanlı elçilerine tayinat ödemek zorunda kalmışlardır. Aslında Avrupalı devletlerin birbirleriyle ilişkilerinde böyle bir uygulama olmayıp erken Osmanlı asırlarında Doğulu/Müslüman devletlere ait bir teşrifattı ki, elçilerin, sultanın misafiri kabul edilmesinin bir sonucudur (Topaktaş, 2015, s. 34; Topaktaş, 2021, s. 3). Aynı zamanda bu sayede elçilerin ülke içindeki faaliyetleri kontrol altında tutulmuş olurken elçinin başına buyruk hareket etmesi engelleniyor ve devletin gözetimi altında bulunuyordu (Düzbakar, 2009, s. 185).

Avrupalı elçiler Edirne üzerinden İstanbul'a gelirken doğudan gelen elçiler Anadolu tarafindan şehre girerlerdi. Bu minvalde İran elçileri unvanlarına uygun bir heyet tarafindan Kartal ve Bostancı Köprüsü’nde karşılanarak Üsküdar'a getirilirlerdi. Burada bir gün dinlendirilirler; bu sırada kendileri için matbah-1 amire tarafından organize edilen yemeklik yerine -özellikle Fenerbahçe bölgesine- götürülüp ağırlanırlardı. İranlı elçilerin rütbesine uygun merasim ve teşrifata büyük önem verilirdi. Sonra Kaptan Paşa veya Bostancıbaşı idaresindeki gemi ve kayıklarla top atışları eşliğinde İstanbul [Avrupa] yakasına geçirilirdi (Kütükoğlu M.S., 1989, s. 212-214; Gerlach, 2010, s. 334-335). Eğer elçi İstanbul'da ağırlanmayacaksa bu defa da konaklayacağı şehre kadar ikinci bir masraf daha yapıldığından devletin harcamaları katlanırdı.

Elçiler getirildikleri şehirde kendileri için kiralanıp hazırlanan saray, konak ve evlerde ağırlanırlardı. Elçi gelmeden evvel buralar temizlenir ve tefriş edilirdi. Yine buraların kiraları, bakımı ve güvenliği devlet tarafından sağlanırdı (Kütükoğlu M.S., 1989, s. 203-211). Mesela 1698 yılında Edirne'ye Sultan II. Mustafa'nın yanına gelen Safevî elçisi Rüstem Han, 
henüz gelmeden Edirne'deki Ahmed Paşa Sarayı'nın temizletilmesi maksadıyla tutulan "1rgad"lara hazineden 30 kuruş (480 akçe) ödeme yapılmıştı (BOA, AE.SMST.II., 32/3188. Evâil-i Zilhicce 1109 / 10 Haziran 1698). Genel uygulamada İslam ülkelerinden gelen elçiler Üsküdar'dan İstanbul yakasına geçirilirler ve burada genellikle Acemi oğlanlar kışlası ve At Meydanı civarında kendileri için hazırlanan konaklarda ikamet ederlerdi. Elçi ve heyetinin güvenliğini yine devlet sağlardı; elçinin kapısında "yasakçı" adı verilen yeniçeriler nöbet tutarlardı (And, 1970, s. 21). İran'a giden Osmanlı elçileri de yine aynı şekilde hazırlanmış devlet adamlarına ait evlerde misafir edilirdi (İskender Bey Münşî, 2019, s. 628).

Elçi ister İstanbul'da isterse başka şehirde ağırlansın, İran'dan gelenlere özellikle de "han unvanı" taşıyanların teşrifatına çok dikkat edilirdi. Yine bu bakımdan geliş ve gidişlerdeki alayların debdebesi ve tayinat ile harçlıkları elçinin İranlı ya da Avrupalı olmasına göre artar veya azalırdı. İran elçilik heyetinin karşılanması hususunda en gösterişli olanlardan birisi 1576 yılında İran Şahı Tahmasb'ın elçisi olan Revan ve Nahçıvan Hâkimi Tokmak Han'ın hediyelerle Sultan Murad'ın tahta çıkışını tebrik ve babası için baş sağlığı dilemek maksadıyla gönderildiği zaman yaşanmıştı (Selaniki, 1999, s. 112; B. Kütükoğlu, 1994, s. 376).

Elçiler; sultanla görüşmeden evvel sadrazam tarafından kabul edilir; şereflerine ziyafet verilirdi. Karşıllklı hediye takdim edilmesi de Osmanlı teşrifatının gereklerindendir. İran elçilerinin Avrupalılara göre üstünlüğü burada da görülürdü. Paşakapısı'na gelen elçi attan iner inmez çavuşlar kâtibi ve emini koluna girerlerdi. Çavuşbaş1, tezkireci, mektupçu, kapıcılar kethüdası ve selam ağası önde olduğu halde avludan arz odasına kadar yürürler; elçiyi önce misafir odasına sonra arz odasına götürürlerdi. Buradaki oturma düzeni de İran elçilerine özeldir. Şahın elçisi sadrazamın yanına, maiyeti elçinin alt yanına oturtulmasına rağmen, Avrupalı elçinin sandalyesi sadrazamın karşısına konurdu (Kütükoğlu M.S., 1989, s. 216-220).

Elçi sultanın huzuruna İstanbul'da çıkarılacaksa İstanbul'a gelişinden ikiüç gün sonra teşrifat gereği alaylarla saraya getirilirdi. Elçinin Sultan'a sunacağı hediyelerin defteri hazırlanırdı. Bu geliş özellikle ulufe divanının olduğu güne rast getirilirdi. Eğer denk getirilememişse "galebe divanı" tertip edilirdi. Elçi saraya getirilmeden önce Müslüman ise Ayasofya Cami'nde sabah namazının kılınmasının ardından III. Ahmed Çeşmesi yakınlarında atı üzerinde sadrazamın gelişi içi bekletilir; sadrazam gelince de 
elçi onu selamlar birlikte saraya giderlerdi (M. S. Kütükoğlu, 1989, s. 221222). Bunların dişında padişah ve sadrazamın elçi kabullerinde gayrimüslim devletlerin elçileriyle aynı teşrifat kaideleri uygulanırdı (Uzunçarşı11, 1988, s. 301).

İran elçilik heyetleri oldukça kalabalık olurdu. Mesela 1740 yılında elçilik göreviyle İstanbul'a gelen Hacı Kulu Han'ın maiyeti 4000 kişiydi (Sevinç, 2012, s. 140-141). Bununla beraber mali açıdan bakıldığında bu kadar kalabalık bir heyete bütün teşrifat kurallarının tam olarak gerçekleştirilmesi, yedirilip içirilmesi, yol masrafları ve hediye verilmesi devlet için büyük bir külfet oluştururdu. Yine de Osmanlı, İran elçilerinin İstanbul yahut sultanın bulunduğu şehre girişinden itibaren, karşılama, konaklatma, ziyafet sofralarında ağırlama ve huzura kabul merasimlerini bir güç gösterisi olarak takdim ederdi (Şahin Allahverdi, 2019, s. 63-64).

Osmanlı Devleti özellikle İran ve diğer Müslüman devletlerin elçilerinin karşılanması, ağırlanması, teşrifat ile verilen tayinat ve hediyeler konusunda Avrupalı devletlerinin elçilerine nazaran daha özenli davranmaktadır. Özellikle Osmanlı'nın Batı'ya karşı üstünlügünü koruduğu yüzyıllarda Avrupalı elçilerin yıllarca padişahın huzuruna çıkamadığı; elçi hanında kaldıkları süre boyunca kendilerine ülkeleri tarafından verilen para ve eşyayı tükettikleri, zor durumda kaldıklarına dair örnekler az değildi (Şahin Allahverdi, 2019, s. 57-70). Bununla beraber devletin ihtişamının azalmaya başladığ 1683 sonrasında incelediğimiz II. Mustafa döneminde, savaş halinde olunmayan İran elçilerine çok daha dostane davranıldığı kanaati hasıl olmuştur. Osmanlı yönetiminin bu tavrı Avrupa cephesinde işler yolunda gitmediği halde içinde bulunduğu zaafiyeti dosta-düşmana belli etmeme çabası olarak yorumlanabilir.

Fevkalade elçilerin tayinatlarının elçinin Osmanlı topraklarında kaldığ süreyi kapsaması esastı. Ancak padişahın huzuruna çıkabilmesi için beklediği süreye göre uzayabiliyordu. Böyle durumlarda ek tayinat defteri hazirlaniyordu (BOA Cevdet Hariciye [C.HR], 134/6698, 6 Cemaziyelevvel 1108 / 1 Aralık 1696). Bu da devletin mali yükünün katbekat artması anlamına geliyordu. Devlet sadece elçi ve heyetinin masraflarını karşılamakla kalmaz; mihmandar gibi maiyetlerine dahil edilen vazifelilere de ayrıca tayinat öderdi. Mesela 1151/1738-1739 y1lında İstanbul'a gönderilen İran elçisi Mehmed Rüstem Han ve Nazır Ali Han'ın mihmandarlığına tayin edilen ağalardan biri Dergah-1 Âli kapıcıbaşılarından Ebubekir Ağa, diğeri 
Bağdad Valisi Ahmed Paşa'nın ağalarından Süleyman Ağa ve Vezir Kaymakam Paşa'nın ağalarından biriydi. Bunların tayinatı toplam 22.712 akçedir (BOA Bab-1 Defteri Baş Muhasebe Kalemi Matbah-1 Amire Eminliği [D.BŞM.MTE]. 11059. 1 Cemaziyelahir 1151 / 16 Eylül 1738).

Tayinat sisteminin dezavantajları sadece Osmanlı yönetimine getirdiği mali yük olmayıp muhatap devletleri de zorluyordu. Avrupalı devletler kendi aralarında ülkelerine gelen elçinin masraflarını karşılamadıkları halde Osmanlı elçilerine aynı teşrifat kurallarıyla mukabele etmek zorundaydılar. Bu da elçilerin sık sık şikâyetçi oldukları bir durumdu. Çünkü her gelişlerinde özellikle padişaha ulaşıncaya kadar devlet kademelerinde olan idarecilere pahada ağır hediyeler vermek zorunda kalıyorlardı (Teply vd., 1969, s. 249; Gerlach, 2010, s. 218).

Tayinat usulü İran diplomasisinin de bir parçasıydı. 1612 senesinde Osmanlı Devleti ile İran arasındaki savaş halinin sona erdirilmesi maksadıyla elçiler teatisi yapıldığı sırada İran'dan İstanbul'a elçi tayin edilen Kadı Han'ın yolculuk masrafları olan 1000 tümen halis altın şahın hazinesinden karş1lanmışt1 (İskender Bey Münşî, 2019, s. 629).

\section{Ebu'l-Ma'sum Han'ın Elçiliği ve Ağırlanması (1696-1697)}

17. yüzyılın sonlarında Osmanlı Devleti batı cephesinde savaşta iken, İran şahı Hüseyin bin Süleyman Şah tarafindan İran'dan iki defa elçi gönderilmişti. Birincisi II. Mustafa'nın (1695-1703) tahta geçişi münasebetiyle cülus tebriki için gönderilen (1008 / 1696-1697), eski Horasan Hâkimi Ebu'lMa'sum Han'dır. Diğer İran elçisi ise Basra'nın anahtarlarını Sultan'a takdim eden Rüstem Han'dır. Osmanlı Devleti'nin Batı cephesinde savaşta olduğu bir ortamda bir ayaklanmayla önce Mani Aşireti'nin ardından Huveyze Hakimi Ferecullah'ın eline geçen Basra, İran Şahı tarafından alınarak anahtarları İstanbul'a gönderilmişti. Her iki elçi de seferde olan sultanın yanına Edirne'ye götürülüp orada ağırlanmıştır (Uzunçarşıllı, 1988, s. 250; bknz. Sevinç, 2012; Kurtaran, 2019, s. 320-321).

Dönemin bürokratlarından ve göz tanığı Teşrifâtî-zâde Mehmed'den aktaran Mercan'a göre (1996, s. 109) elçi Ebu'l-Ma'sum Han, Muharrem ayında (Ağustos 1696) İstanbul'a ulaştı. O zamanın teşrifat usullerince devlet erkânı tarafından karşılandı. Ardından yeme-içme ve konaklama ihtiyaçlar1 verilip birkaç gün dinlenmesi için kendisine ayrılan konağa yerleştiril- 
di. Savaş sebebiyle Sultan ve devlet erkânı Edirne'de bulunduğundan elçi Edirne'ye davet olundu.

11 Ağustos tarihli ve elçiye sadeyağ yağ ve diğer gıdaları için 62.800 akçelik bir masraf yapıldığına dair defter, Teşrifâtî-zâde Mehmed'in elçinin Ağustos ayında İstanbul'a vardığına dair kaydını doğrulamaktadır (Sevinç, 2012, s. 29). Bu durumda İran heyeti A ğustos ayından Kasım sonuna kadar İstanbul'da kalmışlardır. Buna rağmen İstanbul' daki ikametlerinde ödenen tayinatlarını bütün olarak gösteren deftere henüz ulaşılamadı. Bilindiği gibi cülus tebriki için Osmanlı ülkesine gelen elçilere geldiği günden ayrıldığı güne kadar ikamet ettikleri süre için tayinat ödenirdi (Topaktaş, 2015, s. 36).

Elçi ve maiyetindekiler İstanbul'dan Edirne'ye davet edildikten sonra yol boyunca tüketimleri için dokuz günlük tayinat ödenmiştir. Kendilerinin ve hayvanlarının bütün yeme-içme ve kışın ilk günleri olduğundan 1sınma ihtiyaçlarına toplam 410.602 akçelik tayinat hesaplanmıştır (BOA D.BŞM. MTE, 10694. 25 Cemaziyelahir 1108/21 Kasim 1696). Bir kayıtta bu yolculuğun kış şartlarında bir gün konak olmak üzere 11 günde kat edileceğinden (BOA C.HR. 5/522) bahsedilse de yol masrafları dokuz gün olarak hesaplanıp ödenmiş̧ir. İranlıların Edirne'ye varışıyla ilgili olarak ise resmî belgeler ve dönemin tarihçilerinin verdiği tarihler birbirinden farklıdır. Çağdaş tarihçiler (Silahdâr Fındıklılı Mehmed Ağa'dan aktaran Topal, 2001, s. 244; Teşrifâtî-zâde Mehmed'den aktaran Mercan, 1996, s. 110) heyetin 12 Aralık günü Edirne'ye ulaştığını naklediyorlarsa da deftere göre Edirne'deki tayinatın başlangıç tarihi 1 Aralık'tır (BOA C.HR. 134/6698).

Edirne'ye yaklaşan ve Hafza menziline gelen elçi; Yeniçeri ocağından bir çorbac1 ve neferleriyle, üç-dört divan çavuşu refakatinde çavuşbaş1 ağa, sipah ve silahdaran ağaları üzerlerinde selimî ve erkân kürkleri ve Divan-1 Hümayun bisâtıyla; bütün sipah çavuşları ve silahdarlar mücevvezeleriyle karşılamaya gönderildiler. Çavuşbaşı İbrahim Ağa beraberinde padişahın elçiye gönderdiği bir at ve ikramları getirmişti. Elçi Ebu'l-Ma'sum Han alay ile getirilip Selimiye Cami yakınlarında kendisi için hazırlanan eski defterdar Ahmed Paşa sarayına konduruldu. Adet olduğu üzere elçi gelmeden önce şehrin önemli konak/saraylarından biri bedeli hazineden ödenmek üzere döşenirdi ki buna tefriş denilirdi. Aynı şekilde heyetin o günkü yiyecek (mekulat) ve içecekleri (meşrubat) de gönderilirdi. 
Gelişinden itibaren birkaç gün burada dinlendikten sonra 16 Aralık günü ${ }^{1}$ çavuşbaş1 gönderilerek elçi bir gün sonra şerefine verilecek ziyafete davet olundu. Elçiyi almak üzere yine çavuşbaşıyla bir at gönderildi. Çorbacı üst kürkü ve sorgucuyla, neferleri önde üsküfleriyle, çavuşbaşı selimî ve erkân kürküyle ve Divan-1 Hümayûn bisâtıyla donanmış olduğu halde elçi alayla saraya getirildi. Veziriazamın kapıcılar kethüdası ve selam çavuşu elçinin koltuklarına girip atından indirdiler. Veziriazamın tezkirecisi sahn merdiveninde elçiyi karşılayarak önüne düşüp divanhanede saf tutmuş halde bekleyen ağaları selamlayarak arz odasının önüne geldiler. Heyet burada bekleyen reisülküttab ve kethüda tarafindan karşılandılar. Onlar elçinin önünde yürüyerek arz odasında bekleyen birun ağalarını selamlayarak, merdivene vardılar. Orada bulunan Enderun ve Birun ağalarını selamladıktan sonra ziyafet verilen büyük odaya geldiler. Elçi, sadrazamı selamladığında sadrazam ayağa kalkarak elçiye doğru birkaç adım attıktan sonra İran şahının mutemed-i saltanatının (başvezir) yazdığı mektubu sadrazama sundu. O da mektubu reisülküttaba teslim etti ve kendilerine ayrilan yerlerine oturdular.

Odanın sağ tarafinda 15 adet kapıcıbaşı solunda ise 30-40 Enderun ağası saf tutmuş halde hizmetteydiler. Elçi ile tahvildarı meclise alınıp heyetin geri kalanına alti-yedi yerde sofralar kuruldu. Ziyafetten sonra aynı atlarla elçilik heyeti konaklarına gönderildiler. Teşrifâtî-zâde Mehmed, sadrazam ve devlet erkânının, şahın elçisine cülus tebrikine gelen diğer elçilerden daha fazla yakınlık gösterdiklerini ikram, izzet ve saygıda son derece cömert davrandıklarını nakletmektedir (Mercan, 1996, s. 112-113).

Yine müellife göre (1996, s. 114-115) elçilik heyetinin nehrin kenarında kurulan otağa davet edilmeleri 21 Aralık günü toplanan divan zamanına denk getirilmiştir. Kubbe vezirleri, kazaskerler, defterdarlar, nişancı ve diğer divan kâtipleri yerli yerinde toplanmıştı. Sadrazam Mehmed Paşa elçiyi davet için İstabl-1 Amire'den atlarla beraber çavuşbaşıyı gönderdi. Çavuşbaşı divan teşrifatına göre ve diğer çavuşlar mücevvezeleriyle elçinin konağına varıp gönderilen atlarla elçiyi ve heyetini getirdiler. Elçi atından inince heyetin sağında çavuşbaşı, solunda şahın namesini başı üzerinde taşıyan kapıcılar kethüdası olduğu halde dergâh-1 âli yeniçerilerini

Silâhdâr'a göre ziyafete davet tarihi 23 Cemaziyelevvel 1108 /18 Aralık 1696'dir (Nusretnâme'den aktaran Topal, 2001, s. 244). 
selamlayarak geldiler. Adet üzere hazırlanan çorbayı içtikten sonra ağanın mihmandarlığında divanhaneye girildi. Vezirler ile ayan-1 devlet ve erkân-1 saltanat ayağa kalktı. Sadrazam elçiye hürmeten kaymakam Vezir Hasan Paşa'nın alt yanına oturdu. Elçi gelmeden önce şahın hediyeleri önden gönderilmişti. Hediyeler Teşrifâtî Efendi tarafından deftere kaydedildikten sonra "pişkeşci" aracılığıyla Babüssaade önünde sergilenmeye başlanmışt1.

Matbah-1 amire'den yemek geldiğinde, elçinin maiyetindekilere ayrı sofralar kuruldu. Teşrifâtî-zâde Mehmed'den aktaran Mercan'a göre (1996, s. 116) göre elçilik heyeti, elçi dahil 92 kişiydi. Yemekten sonra çavuşbaşı ve kap1 kethüdası elçiyi divanhaneden kaldırdı ve hazine önünde elçinin maiyetindeki herkese hilat ihsan edildi. Yeniçeri ağası, Vezir Mahmud Paşa ve kazaskerler arza girme görevlerini tamamladıktan sonra divandan ayrıld1lar. Bundan sonra veziriazam, vezirler, çavuşbaşı, kapı kethüdası, elçinin de bulunduğu kapıcıbaşıların sofrasına geldiler. Elçiyle beraber tahvildarı ve müftüsü vezirlere katılarak padişahın huzuruna çıktılar. Elçi, şahın gönderdiği nameyi en alttaki vezire uzatt1; o da üst tarafinda olan vezire vererek, mektup elden ele veziriazama kadar ulaştırıldı. Veziriazam da mektubu (bknz. BOA [Divan-1 Hümayun Sicilleri Name-i Hümayun Defteri] A.DVNS. NMH.d, 5, s. 232-238) tahtın kenarına koydu. Padişah elçiden şahın halini hatırını sorduktan sonra elçi huzurdan ayrıldı. Sadrazam da törenden ayrilarak konağına döndü.

Elçilerin devlet adamları tarafından davet edilmesi âdeti gereğince; Rikab-1 Hümayun kaymakamı Vezir Hasan Paşa elçi şerefine bir akşam ziyafet verip kendisine bir de at hediye etti. Elçi de bulunduğu konum itibariyle sadrazamın da izniyle sadece ağaları, kaldığı konağa davet edip onları ağırlayarak mukabelede bulundu. Sadrazam ve Şeyhülislam dahi elçiyi birkaç defa davet edip ikramlarda bulunmuşlardı. Yine aynı müellif; şimdiye kadar İran şahlarından gelen elçilere bu mertebe izzet ve ikram olunmadığını hatta bundan sonra gelenlere de bu derecede ihtimam gösterilemeyeceğini nakletmektedir (1996, s. 117-118). Aynı âdet İran tarafinda da çeşitli zamanlarda, İran Şahı'na gönderilen Osmanlı Sultanı'nın elçilerine karşı tatbik edilirdi. 1051 / 1641-1642 senesinde Sultan İbrahim, "hatırlarını ve muhabbetlerini tazelemek" maksadıyla Kabil Ağa'yı elçi sıfatıyla Şah I. Safi'ye gönderdiğinde elçi şahın huzuruna çıkıp sultanın mektubunu sunduktan sonra İran devlet erkânı ve emirleri tarafindan misafir edilmişti. 
Başta Divan Veziri Mirza Taki olmak üzere sıra sıra büyük ziyafetlerle ağırlanmıştı. Sonrasında yine Osmanlı Devleti'nde olduğu gibi elçiye ve sultanın mektubuna mukabele etmek için Maksud Sultan Hulefa elçilik vazifesiyle Kabil Ağa ile İstanbul'a gönderilmişti (İskender Bey Münşî, 2019, s. 210).

Teşrifâtî-zâde Mehmed Efendi (Mercan, 1996, s. 119-120) göz tanığ olması nedeniyle törenleri canlı bir şekilde tasvir etmektedir. Edirne'de kendilerine hayli izzet ve ikram gösterilen elçi Ebu'l-Ma'sum Han İran'a dönmek için padişahın iznini isteyip veda etmek ve padişahın cevabi mektubunu almak amaciyla 22 Aralık günü Veziriazam Mehmed Paşa tarafından huzura davet edildi. Bölük ağalarının toplantıdan bir gün evvel selîmî ve erkân kürkleriyle sultanın sarayında hazır bulunmaları istendi. 23 Aralık günü ${ }^{2}$ Saraçhane başında olan kasrın kapısında Siniciler kasrı yanında bulunan Haseki ağa odası hizasında hassa bostancıları, nimtane ve tüfekleriyle iki geçeli dizilmiş bekliyorlardı. Siniciler kasrının karşısında üç adet "mülukâne" oba kurulmuştu. Buradaki taş köprünün diğer başında 200-300 kadar hassa baltacıları toplanmıştı. Demir kapının iç tarafında, Babüssaade ağaları, selîmî ve erkân feraceleriyle beklerken kapının sağında dergâh-1 âli kapıcıları, solunda rikab-ı hümayun solakları ve hassa peykleri elbiseleriyle mertebelerine göre dizilmişlerdi. Dış kapının sol tarafında olan sofada mirahur-1 evvel ve mirahur-1 sâni ağalarla diğer dergâh-1 âli kapıcı-başılar hazırdı. Veziriazam Mehmed Paşa alayla tören mahaline varınca, atından inip huzura doğru yürüdü. Çavuşbaşı erkân kürküyle 29 kişiden oluşan divan çavuşları ise mücevvezeleriyle elçinin getirilmesine memur edilmişlerdi. Elçinin sarayına giderek daha önce getirildiği kaide üzere çavuşbaşıyla Saraçhane Köprüsü'nden geçerek köprünün yanında olan kasrın kapısından girip Siniciler kasrı hizasında atlarından indiler. Elçi donatılmış (mefruş) büyük odaya alınıp tazimhanede oturtuldu.

Başka bir ayrıntı ise Silahdâr Fındıklılı Mehmed Ağa tarafından vurgulanmaktadır (Topal, 2001, s. 255-256). Darüssaade ağası "erkân kürk", hazinedar ağası kallavi giyinmiş halde, önden veziriazam daha sonra elçi ve maiyeti Saraçhane Köşkü kapısından Hasbahçe’ye girdiler. Sultan Mustafa kasra geldiğinde sırtında "sarı serâsere dikili semmûr kapanitse" ve başın-

Silahdar, bu tarihi 23 Cemaziülahir/17 Ocak Perşembe günü olarak yazmaktadır (Nusretnâme'den aktaran Topal, 2001, s. 255-256). 
da "küçük destâr" üzerine Hind sorgucu sokunmuş olduğu halde tahtına oturdu.

Yine Silahdâr Fındıklılı Mehmed Ağa'dan aktaran Topal'a göre (2001, s. 254-255) Sadrazam sefer dönüşünde 28 Aralık 1696 günü Edirne'ye gelip huzura çıkmış; ardından padişahın otağı Tunca nehri kenarına kurulmuştu. Padişah eğlence maksadıyla Acemlerin oynadığ çevgan (cirit) oyununu görmek isteyince elçinin heyetindeki Acemlerden 30 kişi otağın bulunduğu yere getirildi. Bu esnada devletin azameti ve kudreti heyete gösterilmek maksadıyla rikap ağaları, solaklar, peykler ve devlet erkanına, mücevherlerle süslü 40 adet atla geçit yaptırıldı. Sultan kendisi için kurulan tahta oturup Tablhane ile iç halkı, harem ağaları ve paşalarla oynanan ciridi ve güreşleri seyretti. Sira çevgan oyununa geldiğinde bizzat padişah oynamak istediyse de başarılı olmadı. Topu yerden çevganla kaldıramadığı için meydanın karlı oluşunu bahane ederek bir hayli mahcup oldu.

Teşrifâtî-zâde Mehmed ise güreş ve çevgandan hiç bahsetmemekle birlikte İstabl-1 amire'deki murassa ve mücevher rahtlı 50 adet atın meydana getirilerek altın, elmas murassa ve mücevher kalkanlı ve sair bisâtlarıyla süslenmiş oldukları halde elçinin önünden geçirildiğini doğrulamaktadır. Aynı şekilde Nusretname'de (Topal, 2001) bahsedilen geçit töreni de ayrıntılarıyla verilmektedir. Teşrifâtî-zâde Mehmed'den aktaran Mercan (1996),

Arpa emini mücevveze ve üst kürküyle; ahur kethüdası mücevvezeyle; mirahur-1 evvel Ahmed Ağa selîmî ve erkân kürküyle 200 nefer ahur hüddamı tören meydanına çıktılar. Mirahûr-1 evvel ve sâni ile kapıcılar kethüdâsı, çavuşbaşı, ser-bostancıyân-1 hassa toplandığ1 yerde elçinin heyetindeki 92 adamına kapıcılar kethüdası tarafından hilat giydirildi. Önce sadece elçi ve iki adamının huzura çıkmasına müsaade olundu. Sağ taraflarında mirahur-1 evvel Ahmed Ağa ve solda Çavuşbaşı İbrahim Ağa, önlerinde sipah ve silahdar ağaları, kapıcı-başı ağalar ve rikab-1 hümayun ağaları olduğu düzende Hasoda'ya varıldı demektedir (s. 121).

Has Oda Köşkü'nün içiyle arzhanenin oturak yerleri değerli kumaş ve mücevherlerle döşenmişti. Sultanın yeri ise "kaba minder ve semmûr ma' kat ile" döşenip kubbeye çiçek şeklindeki "şebîke" elmaslar, onların altına altından çekilmiş top tellerle iri inciler ve kapı kenarına zümrütler asılmıştı. Köşkün dışına ise şadırvanın karşısında ü̧̈ adet taht döşenmiş, ortadaki 
tahtın önüne elmas, yakut, lâl ve zeberced ile süslenmiş altın bir taht; onun sağına ve soluna da abanozdan birer taht kurularak, hepsinin üzeri kıymetli yastık ve minderlerle donatılmıştı. Minderlerin arasına ve her birinin köşesine mücevher sorguçlu birer "destâr-1 hâs pirâste" konulmuştu. Altından olan tahtın üstüne ceviz büyüklüğünde ve kırk-elli adedi bir arada dizilmiş dört top elmas, yakut, lâl ve altın zincirler asılmıştı. Hazîne-i Amire'de muhafaza edilen Mekke-i Mükerreme'den gelen Kâbe kapısı, kasrın dış kapısının sağ tarafında bulunan çeşme üzerine asılmıştı. Kasrın içi ve dışı son derece gösterişli bir şekilde değerli eşya ve mücevherlerle donatılmışt1. Valide Sultan da meclise geldiğinde Has Odalı 40 kişiyi "murassâ' " kuşak ve hançerler kuşandırdı. Yine Harem Ağaları da değerli kumaşlardan mamul elbiseleriyle hazır bulunuyorlard1.

Elçi bir saat kadar veziriazamla birlikte oturup kahve ve şerbet içtikten sonra, ihsan edilen hilatlar veziriazam, elçi ve maiyetindekilere giydirilmişti. Elçiyle beraber; sadece kethüdâsı, defterdârı ve hâcesi Mahmûd Efendi'nin huzura girmesine izin verilmişti. Huzura geldiklerinde Sultan elçiye: Sa 'âdetlü şâh hazretlerine benden selâm eyle gönderdiği nâme ve hediyyesi gelüp, makbulü hümâyûnum olmuşdur. Sen dahi risâlet tarîkıyla ara yerde bulunup güzel hizmet etdüğünden ber-hûrdâr olasın deyip, namesini kendi eliyle teslim etmişti (Silahdâr Fındıklı1ı Mehmed Ağa'dan aktaran Topal, 2001, s. 243; Raşid \& Çelebizâde, 2013, s. 533-534; Defterdar Sarı Mehmed Paşa, 1995, s. 604). Teşrîfâtî-zâde Mehmed ise mektubun Darüssaade ağasına verildiğini ağanın mektubu öptükten sonra Veziriazam Muhammed Paşa'ya; o da öptükten sonra mektubu elçiye verdiğini kaydetmektedir (1996, s. 122; bknz. BOA A.DVNS. NMH.d. 5, s. 238-251; Topal, s. 244-247).

Elçi Ebu' 1-Ma' sum Han, şahın gönderdiği iki adet murassâ' altın kılıç, büyük bir altın tas, bir dişi fil, 45 adet Acem develerinden oluşan hediyeleri ve cülûs tebrik mektubunu sultana takdim etme işini tamamladı. Ertesi gün ise kendi adına 15 deve, 4 yorga (rahvan) bargir, bir miktar akmişe, harir ve zer-baft cinsinden kumaşlar, hulviyyât (şekerleme) ve şekeri sultana iletti (Silahdâr Findıklı1ı Mehmed Ağa'dan aktaran Topal, 2001, s. 243; Raşid \& Çelebizâde, 2013, s. 604; Hammer, 1992, s. 248-249).

Osmanlı diplomasi kuralları gereği elçiye ve muteber adamlarına hilatlar giydirildi. Ayrıca sonradan elçinin yedi-sekiz adamı daha içeriye davet 
edilerek huzura alınmışlardı. Dışarı çıkıldığında elçi; name-i hümayunu kethüdasına verdi. Sultan ayrıca Acem şahına hediye olarak bir adet de at ihsan etti (Teşrifâtî-zâde Mehmed'den aktaran Mercan, 1996, s. 122). Elçi, kethüdası aracılığıyla bir bargiri Sultan II. Mustafa'ya hediye ettiğinde Sultan da elçi ve dört adamına bir kabza altın ve hilatler ihsan etti. Son olarak elçi ve maiyeti huzurdan ayrıldılar (Silahdâr Fındıklılı Mehmed Ağa'dan aktaran Topal, 2001, s. 255).

İran şahlarına ve onların Osmanlı Devleti'ne gönderdiği elçileriyle hizmetkârlarına değerli hediyeler verilmesi de yine Osmanlı diplomasi adetleri arasındaydı. Bunlar değerli kumaş ve mücevherlerle işlenmiş ateşsiz silahlar ve at koşum takımları (bisât)'dan oluşuyordu. Osmanlı'da "bisât" ve "raht" tabiri has ahıra bağl1 Raht-1 Hümayûn Hazinesi'nde bulunan değerli eşya için kullanılmaktadır. Bisât, mücevherât, zer-i sâfî, sim mutallâ, sâde, gaddare, altın zincir, abâyi vb. eşya hazinenin başında bulunan hazinedar-1 evvel ağa nezaretinde raht ve bisât defterlerine kaydedilirdi (Özlü, 2013, s. 277-278). İran şahına, elçisine ve elçinin kethüdasına hediye edilen "bisât" da yine bu hazineden verildi.

Padişah tarafindan Şah için ihsan edilen "murassâ' divan rahtı, abâyî, rikâb, som yapuk ile eyerlenmiş doru küheylan" köşk merdiveninde hazır bekliyordu. Elçi ve adamları, Mirahûr-1 evvel Ahmed Ağa aracılı̆̆ıyla kendilerine ihsan edilen atlara binerek konaklarına döndüler. Birkaç gün sonra Sadrazam Muhammed Paşa'nın şahın vezirine yazdığı cevabî mektubu (bknz. BOA A.DVNS. NMH.d, 5, s. 280-289) da elçiye teslim edildi. Baş-kapıkulu Osman Ağa aracılığıyla Hazine-i Amire'den elçiye 40 kese, maiyeti için 10 kese harcirah verilerek baharda Erzurum yoluyla ülkelerine dönmelerine izin verildi. Padişahın kendi hattıyla yazdığı sülüs hatlı Besmele-i şerif ile âyet-i kerime gümüş kubur içine koyularak arkasından elçiye gönderildi. Günlük “nafaka baha” (tayinat) olmak üzere 200'er kuruş tayin edilirken mutfaklarının hizmetinde vekilharç Seyfi Ağa ile divan çavuşlarından iki-üç çavuşun harcırahları da teslim edildi. (Silahdâr Fındıklılı Mehmed Ağa'dan aktaran Topal, 2001, s. 256-257; Teşrifâtîzâde Mehmed'den aktaran Mercan, 1996, s. 123-124, 258-368). Silahdâr Mehmed Ağa (2001, s. 257) elçinin, padişahın ve ortamın gösterişinden şaşkınlık içinde kaldığını ve padişaha dua etmekle yetindiğini; huzurdan ayrılırken son derece hislendiğini ve gözlerinden yaşlar aka aka konağına döndüğünü kaydetmiştir. 
Defterdar Sarı Mehmed Paşa (1995) elçi’ye

İstabl-1 âmireden sîm (gümüş) zencir ve gerdâne; bilanlı zümrüt ve yakutla süslü altın kaplama divan rahtı (eyer takımı); yakut ve pirûze ile işli yeşim kabzalı altın kaplama gaddâre (uzun kama); sîm topuz; minâ-kâri yaldızlı sîm rikâb (üzengi); kaşları sîm kabâreli kadife eyer; zer-dûzi 'abâyî ile müzeyyen bir at; elçinin kethüdasına da kemer-i raht ma'ahû reşme (atın alnına takılan süslü zincir), altun kaplama sîm gaddâre, sîm rikâb, kadife eyer, sırmalı çuka zeyl-pûs ile müzeyyen bir adet at; Şaha has ahur hazinesinden altın zincir, murassa bilan, ökselik, gerdâne, yakut ve zümrütle murassa minâ-kârî altın raht; elmasla murassa sorguç; yakut, zümrüt ve elmaslı topuz; sîm kabzalı yakut ve zümrütle müzeyyen altın gaddâre; yakut ve elmasla murassa yaldılı sîm rikâb; inci ve zümrütle müzeyyen kadife eyer; inci, zümrüt ve yakutla müzeyyen sarı dibâ 'abâyî; atlas astarlı zerdûzi kırmızı çuka yapak; sîm yedek-deş ile müzeyyen bir at verildiğini nakletmektedir (s. 605).

Raşid ve Çelebizâde (2013) hediyeleri biraz daha farklı olarak, bir altın zincir, murassa bilân, enselik, gerdâne, yakut ve zümrüt ile murassa altın raht; yakut, zümrüt ve elmasla işlenmiş deppus, altın gaddare, elmas ile murassa sorguç, yakut ve elmas ile müzeyyen yaldızlı sîm rikâb, inci ve zümrüt ile murassa kadife eyer, inci ve zümrüt ile işlenmiş sarı dîbâ abâyî, al atlas astarlı kırmızı çuka zerdûz yapak ve sîm-i yedek-deş ile donanmış bir rahş-1 dil-keş şeklinde kaydetmiştir (s. 534).

Yakın tarihlerde ağırlanan İran elçisi Rüstem Han'ın kendisine ihsan edilen ve ayrıca mukabele olarak elçiyle Şah'a gönderilen hediyeler (bisât) ise neredeyse aynı paha ve ziynete sahiptir. Bu hediyelerin işçiliğinde kullanılan mücevheratın cinsi ve boyutları, 5287,5 kuruş olan maliyeti ve kumaşların özellikleri müstakil bir defterde kayıtlıdır. Şaha hediye olarak elmas ve yakutlarla işlenmiş licâm (gem-dizgin), saf altın ve zümrütle işlenmiş bilân ${ }^{3}$, saf altın ve lale şeklinde elmaslarla işlenmiş sorguç; altın yaldızlı, yakut ve zümrütle işlenmiş enselik; gümüş yaldızlı yakut ve zümrütle işlenmiş gerdân; saf altın zincir; saf altın, yakut, zümrüt ve elmasla işlenmiş topuz; altın ve gümüş işlemeli diba üzerine yakut, zümrüt ve incilerle be-

Atın boğazına vurulan gülpüser. 
zenmiş topuzluk; saf altın, yakut ve zümrütle bezeli gaddâre; altın ve gümüş üzerine elmas ve yakut işlemeli rikâb (üzengi); kırmızı kadife üzerine altın ve gümüş işlemeli, inci ve zümrütle bezeli zîn (eyer); altın ve gümüş işlemeli diba üzerine inci, zümrüt ve yakutla süslü abâyî elçiye teslim edilmiştir. Sadece, bozulup tekrar yaptırılan, mücevherli bir "tirkeş" (ok kabı) için gereken inci, lâl, zümrüt ve sırma; dibâ-yı Acem bahası; kuyumcu ve sarracların ücretleri 527 iken bütün hediyelerin toplamı 5.287,5 kuruş tutmaktadır. Elçiye ve onun kethüdasına ihsan edilen eşya, doğal olarak şaha gönderilecek eşyaya nazaran sayı, kıymet ve gösteriş bakımından daha azdir (BOA AE.SMST.II, 109/11978, 14 Zilkade 1109 / 24 May1s 1698).

Hammer'e göre (1992, s. 260) ise Rüstem Han'la gönderilen hediyeler arşiv ve dönemin tarihçilerine ait kayıtlardan tamamen farklı ve eksiktir. Hediyeler altın, inci ve değerli taşlarla süslü birer sorguç, ok muhafazası, yay; bir deste altın yaldızlı ok, kıymetli taşlarla bezenmiş asalar ve iki saatle, kalkan şeklinde bir saat; yedi Cezir tüfeği, İstanbul'da ve Avrupa'da dokunmuş değerli kumaşlar; şal, eşarp, yastık ve kemerlerden oluşuyordu.

Yukarıda da değinildiği gibi elçi ve maiyetindekiler aralık ayında normalde üç-beş gün süren görevlerini tamamlamalarına rağmen toplam 77 gün Edirne'de ikamet ettiler. Bunun nedeni 15 Şubat'a kadar kışın şiddetinin geçmesini beklemek zorunda kalmalarıdır. Rüstem Han ve Ebu'l-Ma'sum Han'ın Edirne'de kaldıkları süre ve günlük tayinat bedelleriyle maiyetlerindeki kişi sayısı birbirine oldukça yakındır. Ebu'l-Ma'sum Han'ın heyeti 92 iken, Rüstem Han'ın heyeti 100 kişiliktir. Rüstem Han Edirne'de 69 gün kalmıştır (Sevinç, 2012, s. 36, 202) Bu süredeki tayinatı günlük 190,5 kuruş olup 100 kişi olan adamlarına günlük 15,5 kuruş; Edirne'den İstanbul'a varıncaya kadar oturağı (konak) ile 10 günlük elçi masrafi için 1.905 kuruş tayinat bedeli hazineden karşılanmıştır (BOA AE.SMST.II, 102/11059, 28 Şevval 1109 / 20 Mayıs 1697).

\section{Elçilik Heyetinin Günlük Masrafları}

Yukarıda bahsi geçen hediye ve ihsanlar dışında nakit ve hizmet alımı ve harcırah için devletin karşıladığı masraflar da önemli bir yekun oluştururdu. Silahdâr Fındıklılı Mehmed Ağa (Topal 2001, s. 256-257) ve Teşrifâtî-zâde Mehmed Efendi'ye (Mercan, 1996, s. 123-124) göre Hazine-i Amire'den nakit olarak 2,5 milyon akçe (20.833 kuruş) harcırah ödenmişti. Raşid 
ve Çelebizâde'ye göre (2013, s. 534) elçiye 15 bin, kethüdasına ve tahvildarına 5 biner, toplam 25 bin kuruş tayinat verilmiş olup Edirne'de ve İstanbul'da ikametiyle yol için verilen meblağdan başka elçinin masrafları 261,5 keseyi buluyordu. Bu da yaklaşık 110 bin kuruşluk bir masraf demektir ki müellif bu hesaba hediyeleri de katmış olmalıdır. Defterdar Sarı Mehmed Paşa ise bu rakamlara, elçinin ser-zendârına verilen 5.000 kuruşu da ilave etmektedir (1995, s. 605).

Devletin muhasebe kayıtlarına göre ise sadece elçi ve maiyetinin 77 günlük yani 2.5 aydan biraz fazla süren Edirne ikameti masrafi toplam 23.005,5 kuruş olup günlük 300 kuruşa tekabül etmektedir. İlk önce Ebu'l-Ma'sum Han'ın heyeti için 60 günlük bir tayinat ödenmesi planlanmış; ancak kalacakları süre uzayınca 17 gün daha ilave edilmiştir. 6 Cemaziülevvel 1108/1 Aralık 1696 tarihinden 6 Receb/29 Ocak 1697 tarihine kadar 60 günlük bir tayinat hazırlanmıştır. Buna göre elçi ve heyetinin "zehayir bahası" ve "ücârât" (hizmet alımı) masrafi 2.466.870 akçe olup (120 akçeden) 20.557, 1 rub' kuruş tutmaktadır. Ancak narh defteriyle karşılaştırıldığında bazı gıda ürünlerinin tutarının 2.025,5 1 rub' kuruş fazla hesaplandığ1 anlaşılmış ve düzeltilerek 18.531,5 kuruş olarak güncellenmiştir. Bazı ürünlerin birim bazındaki fiyatı defterde yeniden ve kırmızı kalemle düşürülmüş ancak gün ve sayıyla günlük tayinat miktarının çarpımıyla elde edilen sonuçlar değiştirilmeden bırakılmıştır. Bu nedenle de Ek 1'de görüleceği üzere tabloda eski rakamlarla yapılan hesaplar yer almaktadır (BOA C.HR, 134/6698, 20 Receb 1108/12 Şubat 1697). Bununla beraber sonraki 17 günlük tayinat, tamamen düzeltilmiş rakamlarla hesaplanmıştır. Mevcut rakamlarla heyetin sadece Edirne'deki günlük masrafı yaklaşık 300 kuruşun biraz üstündedir.

Tayinat detaylarına baktığımızda, masraflar birkaç kaleme ayrılmaktadır: Elçinin hizmetinde çalıştırılanlar ve konaklaması sırasında kullanılan konağın ferşi (donatma) için alınan tekstil ürünleriyle mutfak gereçlerinin tedariki önemli bir meblağ tutmaktadır. Yaz-kış aydınlatma için kandil ve kandil yağı; 1sınma ve yemek pişirme için odun ihtiyacı da ev sahibi devlet tarafından sağlanmaktadır. Ebu'l-Ma'sum Han'ın 60 günlük Edirne ikameti sırasında kendisine hizmet eden yardımcılar ve tekstil (mefruşat) ve mutfak gereçleri ile aydınlatma masrafi 240 kuruştur. Misafirlerin kullanımına sunulan eşyalar sıradan olmayıp devrin kıymetli malzemelerinden 
mamul olanlar tercih edilirdi.

Eşya ve yeme-içme harcama kalemleri dışında elçilerin ikameti boyunca hizmetinde görev yapan çeşitli kişilere yaptıkları işin mahiyetine göre yevmiye ödenmektedir. Bu miktar ilk 60 gün için toplam 205 kuruş olup bunun 150 kuruşu elçinin hizmetinde çalışan 10 kişilik bir ekip olan vekilharç, mehteran-1 hassa, kâtip, odun yarıcı, kilerciye; 20'şer kuruşu suyolcu ve neccerâna; 15 kuruşu ise tespit edilemeyen bir hizmet erbabına ödenmişti. Aynı kalemin 17 günlük toplamı ise 110,5 kuruştur. 77 gün boyunca satın alınan hizmet ve malların birim fiyatları ve toplamları Tablo 1, Tablo 2 ve Ek 1'de verilmiştir.

\section{Tablo 1}

Ebu'l-Ma 'sum Han'ın 60 günlük mefruşat ve hizmetli masraflarl

\begin{tabular}{|c|c|c|c|}
\hline Ürün/Hizmet & Miktar/Birim & & Ücret \\
\hline Tuz & 90 kıyye & & \multirow[t]{2}{*}{800} \\
\hline Katran & 100 kıyye & & \\
\hline Hasır Mısrî & 1 aded & & 300 \\
\hline Hasır kaba & 100 aded & & 1000 \\
\hline Kaşık sedefkârî & 3 deste & & 880 \\
\hline Peşkir beyaz & 1 aded & & 360 \\
\hline Fincan & 10 aded & & 150 \\
\hline Kahve ibriği ve tabak & 1 aded & $150+150$ & 300 \\
\hline $\begin{array}{l}\text { Kaşık-1 kilisker? ma' } \\
\text { tabak-1 fağfurî }\end{array}$ & & & 300 \\
\hline Kaşık-1 siyah & 3 deste & & 90 \\
\hline Peştamal & 5 aded & & 570 \\
\hline Kilid & 30 aded & & 90 \\
\hline Kandil ma' kapak? ${ }^{4}$ & 15 aded & & 175 \\
\hline Makrame-i havlu & 1 çift & & 260 \\
\hline Peşkir-i Dimyad & 1 aded & & 480 \\
\hline S1fra-i Yemenî? & 1 çift & & 440 \\
\hline Sünger & 5 aded & & 90 \\
\hline Çarub-1 Mısri (süpürge) & 2 aded & & 60 \\
\hline
\end{tabular}

4 Okunamayan ürün isimlerinin yerine “...” üç nokta; okunuşundan emin olunamayan ürün isimleri içinse “?” soru işareti konulmuştur. 


\begin{tabular}{|c|c|c|c|c|}
\hline Ab-1. & \multicolumn{3}{|l|}{$1 \ldots$} & 100 \\
\hline 'Muşamma' & \multicolumn{2}{|l|}{1 top } & & 150 \\
\hline $\begin{array}{l}\text { Baha-yı kalay ve ücret-i } \\
\text { kalaygirân }\end{array}$ & \multicolumn{2}{|l|}{ 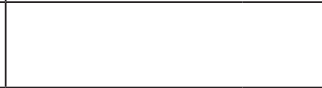 } & & 3000 \\
\hline Na'lince & \multicolumn{2}{|l|}{6 çift } & & 240 \\
\hline Kürek-i nân & \multicolumn{2}{|l|}{1 aded } & & 90 \\
\hline Sabun & \multicolumn{2}{|l|}{25 aded } & & 50 \\
\hline \multirow[t]{2}{*}{ Kağıd } & \multicolumn{2}{|l|}{30 deste } & & 300 \\
\hline & \multicolumn{2}{|l|}{ Ücârât } & & \\
\hline $\begin{array}{l}\text { Berây-1 tayinât-1 vekilharç } \\
\text { ve mehterân-1 hassa ve } \\
\text { hüddemân-1 sâire }\end{array}$ & \multicolumn{2}{|l|}{ Neferen 10 (kişi) } & $\begin{array}{l}\text { Fî-yevm } \\
150 * 60 \\
\text { gün }\end{array}$ & $\begin{array}{l}9000 \text { akçe } \\
\text { (75 guruş) }\end{array}$ \\
\hline \multirow[t]{3}{*}{ Berây-1 hammâliye-i eşyâ } & \multicolumn{2}{|c|}{ Hammâliye-i bakkal } & 30 guruş & 80 guruş \\
\hline & \multicolumn{2}{|c|}{ Hammâliye-i attâr } & 30 guruş & \\
\hline & \multicolumn{2}{|c|}{$\begin{array}{l}\text { Bazı hammâliye-i } \\
\text { sâire }\end{array}$} & 20 guruş & \\
\hline \multicolumn{4}{|l|}{ Yekün } & 240,5 guruş \\
\hline Ücârât & \multicolumn{3}{|l|}{ Nefer (kişi) } & \\
\hline \begin{tabular}{|l} 
Bazara giden \\
Mehteran-1 hassa \\
Kâtip \\
Kilârcı \\
Meremmetci \\
Odun yarıc1 \\
\end{tabular} & $\begin{array}{l}2 \\
3 \\
1 \\
1 \\
1 \\
2\end{array}$ & \multicolumn{2}{|c|}{$\begin{array}{l}\text { Günlük } 30 \\
\text { akçe*60 gün*10 } \\
\text { kişi }\end{array}$} & 18000 akçe \\
\hline Ücret-i neccarân & 60 gün*40 akçe & & & 2400 \\
\hline Ücret-i suyolcu & 60 gün*40 akçe & & & 2400 \\
\hline$\ldots$ & 60 gün*30 akçe & & & 1800 \\
\hline Yekün & \multicolumn{4}{|c|}{24.600 akçe (205 guruş) } \\
\hline
\end{tabular}

Not. Başbakanlık Osmanlı Arşivleri, Cevdet Hariciye (C.HR.) 134/6698.

Misafir heyetin temizlik malzemeleri ile yemek ve ekmek pişirmek için gerekli mutfak eşyası ve yazışmalarda kullanacakları kâğıda kadar bütün ihtiyaçları düşünülmektedir. Heyetin 92 kişi olduğu göz önüne alınırsa eşyaların miktarı veya adedi az bile sayılır. Örneğin üçü sedefkâri olmak üzere altı deste kaşık ve ayrıca sayısı belirtilmeden "tabak ma' kaşık" verilmiştir. O halde toplam en az 60 adet kaşık satın alınmıştır. Bu kadar kalabalık bir gruba altı çift nalince ile sadece bir kahve ibriği ve 10 fincan verilmesi; bazı eşyaların sadece elçiye yahut kıdemli kimselere mahsus olduğunu düşündürmektedir. 
Edirne'de ülkesine dönmek için sultanın iznini bekleyen elçinin dönüşü geciktiğinden ikinci bir tayinat daha hazırlanmış ve defter edilmiştir. 7 Receb 1108/30 Ocak 1697 ile elçinin dönüş günü olarak belirlenen 23 Receb 1108/15 Şubat 1697'ye kadar 17 günlük tayinat 4.474 kuruş tutmaktadır. Bunun 110,5 kuruşu ücerât (satın alınan hizmet) için harcanmıştır. 70 küsur kuruşu yardımcı hizmetlerde kullanılan 10 kişinin yevmiyesi ve 37 kuruşu ise hamaliye hizmetine sarf edilmiştir. Bu ödemelerin defteri son derece detaylı olarak tutulmuş olup satın alınan eşya veya hizmetlerin birim fiyatı ve toplamları Tablo 2'de yer almaktadır.

\section{Tablo 2}

Elçi heyeti için ödenen 17 günlük hizmetli bedelleri

\begin{tabular}{|c|c|c|c|}
\hline Ücretler & Nefer/kişi & & Tutar \\
\hline \begin{tabular}{|l} 
Bazara giden \\
Mehteran-1 hassa \\
Kâtip \\
Kilarc1 \\
Meremmetci \\
Odun yarıc1 \\
\end{tabular} & $\begin{array}{l}2 \\
3 \\
1 \\
1 \\
1 \\
2\end{array}$ & $\begin{array}{l}10 \text { nefer* } 17 \text { eyyam }=170 \\
\text { Günlük } 30 \text { akçe*170 }\end{array}$ & 5100 akçe \\
\hline Ücret-i suyolcu & & 17gün* günlük 40 akçe & 680 akçe \\
\hline $\begin{array}{l}\text { Tayinât-1 vekilharç ve } \\
\text { Mehterân-1 hassa ve } \\
\text { Hüddemân-1 sâire }\end{array}$ & & $\begin{array}{l}10 \text { nefer *yevmiye } 150 \\
* 17 \text { gün }\end{array}$ & 2550 akçe \\
\hline Keresteî & & Günlük 30 *17 gün & 510 akçe \\
\hline Hamâliye-i eşya & & $\begin{array}{l}\text { Bakkal } 15 \\
\text { Attar } 12 \\
\text { eşyâ-yı sâire } 10 \\
\end{array}$ & 37 guruş \\
\hline Yekün & & & $\begin{array}{l}\text { 110,5 Esedi } \\
\text { guruş }\end{array}$ \\
\hline
\end{tabular}

Not. Başbakanlık Osmanlı Arşivleri, Cevdet Hariciye (C.HR.) 134/6698.

Elçi ve maiyetinin iki buçuk aydan fazla süren Edirne ikametinin sadece yeme içme ve konaklama gideri 23.005,5 kuruş tutmaktadır. Edirne'de kaldığ1 süre boyunca Ebu'l-Ma'sum Han ve maiyetine her gün için kasapbaş1 tarafindan 15 koyun verilmiştir (BOA AE.SMST.II, 27/2677. 6 Cemaziyelevvel 1108/1 Aralık 1696). Aynı şekilde ekmekçiler kethüdası aracılığıyla 
verilen ekmeğin her biri 110 dirhem ağırlığında olup günlük toplam 230 vukıyyedir ve bunun rayiç bedeli 836 akçedir (BOAAE.SMST.II, 16/1550. 15 Şevval 1108/7 Mayıs 1697). Edirne'deki firıncı esnafı aracılığıyla verilen ekmeklerin günlük fiyatı elçinin kaldığı 77 gün ile çarpıldığında sadece ekmeğin devlete maliyeti 64.372 akçe tutmaktadır.

Elçileri bir yerden bir yere taşıyan arabaların temini ve ücretlerinin verilmesi arabacılar kethüdasının göreviydi. Acem elçisinin Edirne'den İstanbul'a kadar eşyalarının nakli için 15 adet at arabası tahsis edilmiş, bu hizmet karşıllı̆̆nda arabacılara araba başına 10 kuruş, toplam 150 kuruş ödenmiştir (1 kuruş*160 = 24.000 akçe) (BAO AE.SMST.II, 107/11659. 18 Receb 1108/10 Şubat 1697).

Elçinin maiyetinde bulunanların ikameti için Edirne'deki Ayşe Hatun Hanı'nda oda kiralanmıştır. Tayinat defteri 77 günlük olmasına rağmen, hanın kirası 75 gün üzerinden hesaplanmıştır ki günlüğü üçer paradan, toplam 1.725 para (43 kuruş 125 para) tutmaktadır (BOA İbnülemin Hariciye [İE.HR], 4/424. 26 Receb 1108/18 Şubat 1697). Ancak üçer para ücret, kişi başına değil de oda kirası (günlük toplam 23 para) şeklinde hesaplanmış olmalıdır; zira toplam ücret üçe bölündüğünde 575 rakamına ulaşılmaktadır ki İran heyeti bu kadar kalabalık değildi. Bu nedenle handa kaç kişinin kaldığını tespit etmek oldukça zordur. Zaten elçinin bütün adamlarının tek bir yerde kalıp kalmadığı da bilinmemektedir.

Ebu'l-Ma'sum Han'ın dönüşü esnasında Edirne'den İran sınırına kadar olan masrafları konaklanan menzillerin gelirlerine mahsuben karşılanacakt1. Bunun 966,5 kuruşunun Sivas eyaleti nüzul ve avarız bedelinden (BOA AE.SMST.II, 28/2753); 777 kuruşunun ise Gümüşhane mukataasından ödenecektir (BOA AE.SMST.II, 59/6140. 9 Ramazan 1108/1 Nisan 1697).

Elçinin geri dönüşünde maiyetine görevlendirilen Osmanlı memurlarının masrafları yine tahsisat yoluyla karşılanmıştır. Bunun ilginç örneklerinden biri de Ebu'l-Ma'sum Han'ın dönüşünde kendisine refakat edecek kafilede bulunan emektarlardan el-Hac Seyfi Ali'ye verilen tahsisattır. Kendisi Tokat'ta sahip olduğu 40.560 akçelik zeametin artık çürük olduğunu beyan ile bunun yerine hizmetine karşılık başka bir yerden malikâne talep ettiğinde, kendisine Karlıili'ne bağlı bir köyün geliri malikâne usulüyle tevcih edilmiştir (BOA AE.SMST.II, 40/3914). 
Ebu'l-Ma'sum Han'ın dönüşünde kendisine Kars'a kadar refakat edecek olan beş nefer çavuşun her birine 55'er kuruş olmak üzere, toplam 275 kuruş harcırah belirlenmiştir (BOA AE.SMST.II, 19/1866).

Tayinatlarla ilgili tespit edilemeyen bazı yönleri de vurgulamak yerinde olacaktır. Mesela; ülkesine dönen elçi Edirne'den tekrar İstanbul'a geldiğinde burada kaç gün kaldı ve kendisi için ne kadar masraf yapıldı? Gelişi ve dönüşü arasında geçen süre toplam ne kadardır? Yol boyunca menzillerde zaman zaman yapılan ödeme giderleri parça parça olsa dahi bunların tarihlerinden yola çıkılarak kabaca bir tahminde bulunulabilir. İranlılar Bolu, Çağa ve Gerede menzillerinde konakladıklarında kendilerine günlük 38.666 akçelik zahire bahası verildiğini gösteren kaydın tarihi 29 Nisan 1698'dir (Sevinç, 2012, s. 35). Kayıt tarihleriyle konaklama günleri birebir aynı olmasa da bir fikir vermesi açısından önemlidir. En azından Ebu'Masum Han'ın en geç Nisan ayının sonlarına doğru Üsküdar'dan ayrıldığ varsayılabilir. Yine aynı yöntemi kullanarak heyetin, dönüşü sırasında İstanbul ikametinin süresini de hesaplanabilir. Edirne'de elçiye ödenen tayinat 15 Şubat [1698] gününde sona erdiğine göre, bu tarih, heyetin ayrılma tarihi olarak kabul edilebilir. Edirne-İstanbul yolunun, daha önce yolculuk için verilen tayinat gün sayısından 11 gün sürdüğü bilindiğine göre, 26 Şubat'ta İstanbul'a varmış olmalıdırlar. Bolu'da bulundukları Nisan ayına kadar en az bir ay, Üsküdar'da ikamet ettikleri düşünülebilir. Zira Rüstem Han'ın, dönüşte Üsküdar'da 27 gün konaklamış olması (Sevinç, 2012, s. 36) da bu çıkarımı desteklemektedir.

Ebu'l-Ma'sum Han'ın elçiliğine dair hazırlanan tayinat defterleriyle, hazine temessükleri ve makbuzlarında yapılan masraflar konusunda bazı detaylar mevcuttur. Başta yeme içme, yakacak, aydınlatma ve kaldıkları sürede onlara hizmet eden kişilere (mehteran, vekilharç, kâtip, kilerci, suyolcu, hamal vd.) ödenen yevmiyelere kadar dönemin hizmet fiyatlarına dair bilgiler bulunmaktadır. Yine aynı kayıtlardan elçilerin ağırlandığı konak/saray ve evler için ödenen kiralarla buraların temizlik ve mefruşatı için yapılan harcamaları; ayrıca elçinin bütün masraflarına tahsis edilen mukataa/vergi kaynakları takip edilebilmektedir. İlaveten; sancak ve kaza idarecilerine gönderilen emirler sayesinde elçi ve heyetinin giderleri için hangi kazanın ne kadar ödeyeceği anlaşılmaktadır. Bir başka husus olarak; tayinat defterlerinde verilen ürün/hizmetlerin birim ücretleriyle hizmet/ ürün gün sayısı çarpılarak hesaplandığında, defterde verilen sonuçlarla, 
elde edilen rakamlar arasında farklılıklar çıkabilmesidir. Bunlar da tablolarda dipnotlarla belirtilmiştir (bknz. Ek 1).

\section{Sonuç}

Osmanlı Devleti diplomasi tarihinin bir parçası olan elçilik müessesesi ve ona bağlı olarak elçilere ödenen tayinat uygulamasının, Batılı ve Müslüman devletlere mahsus farklı yönleri mevcuttu. Yapılan bu çalışmayla, İran elçisi Ebu'l-Ma'sum Han'ın elçilik misyonunun Osmanlı açısından son derece anlamlı ve olumlu karşılandığ görülmüştür. Evvela Osmanlı Devleti'nin Batı cephesinde savaş halinin devam ettiği, savaşın ne zaman ve nasıl biteceğinin belli olmadığ 1 ayrıca cephelerden ardı ardına olumsuz gelişmelerin yaşandığı bir zamanda tahta geçen Sultan II. Mustafa'nın; tahta geçişinin tebrik edilmesi suretiyle İran Şahı tarafından "tanınmas1", Osmanlı yönetiminin memnuniyetine sebep olmuştur. İlaveten; İran Şahı'nın elçi aracılığıyla dostluk göstermesi en azından Doğu'da barışın devam edeceğinin bir işareti olarak algılanmış olmalıdır. Çünkü Ebu'lMa'sum Han'ın elçilik görevini tamamlamasının hemen ardından gelen elçinin Basra'nın anahtarlarıyla Şah tarafından İstanbul'a gönderilmesi bunu teyit eden bir durumdur. Şahın güvenini tazeleyen Osmanlı yönetimi memnuniyetinin bir yansıması olarak elçiler nezdinde İran'a karşı dostluktan öte bir tavır sergilemiştir. Hatta; Sadrazamın İran Şahı'na yazdığı mektupta sultanın "kafire karşı" "gaza" halinde olduğunun altının çizilmesi de İran'a atfedilen önemi göstermektedir.

Diğer yandan -hiç değilse- devlet teşkilatı bakımından benzer olan iki ayrı Türk ve Müslüman devlet arasında elçilik müessesesinde uygulanan teşrifat ve merasimlerde mütekabiliyet esasının uygulandığ 1 görülmüştür: Elçilere hazineden tayinat ödenmesi, misafir elçinin ev sahibi ülkenin önemli konaklarından birinde ağırlanması, mihmandarlık hizmeti, elçinin önce sultanın huzuruna çıkıp kendi sultanının mektubunu sunduktan sonra ev sahibi ülkenin devlet büyüklerince kendi konaklarına davet edilerek izzet ve ikramlarda bulunulması, elçilerin ülkelerine dönerken getirdikleri hediyeler ve mektuba mukabele edilmesi bu meyandadır. Bu mektupların içeriği elçiye ve onun temsil ettiği sultanına gönderilen hediyelerin pahaca ağırlığı "azamet" ve/veya "dostluk" tezahürü olarak sunulmuştur. Zira artarda ağırlanan iki misafir elçiye evvelki İran elçilerinden daha büyük ih- 
timam ve debdebe gösterildiğini çağdaş kaynaklar vurgulamaktadır. Edirne'deki elçi kabulleri ve teşrifat kurallarına bakıldığında İstanbul'da İran elçisine nasıl muamele ediliyorsa başkent dışında yine aynı şekilde aynı merasimlerle ağırlama yapıldığ 1 tespit edilmiştir.

17. yüzyılın son yıllarında (1696-1698) İran elçilerine verilen tayinat benzerdir. Ebu'l-Ma'sum Han ve Rüstem Han'in tayinatında bulunan gida, yakacak ve ikamet giderleriyle, adamlarının maiyetine verilen Osmanlı memurlarının masraflarının maliyeti birbirine yakındır. Zira elçinin adamlarının sayıları ve Osmanlı Edirne'de ikamet süreleri de aşağı yukarı aynıdır. Olağan koşullarda İran elçilerinin geliş ve dönüş yolculuğu dahil Osmanlı Devleti topraklarında geçirdikleri süre yaklaşık bir yıldır. Bu kadar bir sürede elçinin bir yerden bir yere naklinde yeme-içme, yakacak, aydınlatma, kalacak yer ve hayvanlarının gereksinimlerinin geçtikleri güzergahlardaki kaza idaresince aynî olarak karşılanması büyük bir organizasyonu gerektirdiği gibi büyük bir malî külfeti beraberinde getirmektedir.

\section{Beyan}

$\mathrm{Bu}$ makale etik kurul kararından muaftır. Çalışmada katılımcı bulunmamaktadır. Çalışma için herhangi bir kurum veya projeden mali destek alınmamıştır. Çalışmada kişiler ve kurumlar arası çıkar çatışması bulunmamaktadır. Telif hakkına sebep olacak bir materyal kullanılmamıştır.

\section{Disclosure}

The article is exempt from the Ethics Committee Decision. There are no participants. The author received no financial support from any institution and there's no conflict of interest. No material subject to copyright is included. 


\section{Kaynakça}

And, M. (1970). XVI. yüzyılda elçilikler ve elçiler. Hayat Tarih Мecmua$s l,(3), 20-25$.

Arı, B. (2004). Early Ottoman diplomacy: Ad hoc period. İçinde A.N.

Yurdusev (Ed.), Ottoman diplomacy studies in diplomacy (pp. 36-65).

Palgrave Macmillan. https://doi.org/10.1057/9780230554436_3

Başbakanlık Osmanlı Arşivleri, Ali Emiri Sultan Mustafa II. (AE.SMST. II.) $102 / 11060$.

Başbakanlık Osmanlı Arşivleri, Ali Emiri Sultan Mustafa II. (AE.SMST. II.) $107 / 11659$.

Başbakanlık Osmanlı Arşivleri, Ali Emiri Sultan Mustafa II. (AE.SMST. II.) $16 / 1550$.

Başbakanlık Osmanlı Arşivleri, Ali Emiri Sultan Mustafa II. (AE.SMST. II.) $19 / 1866$.

Başbakanlık Osmanlı Arşivleri, Ali Emiri Sultan Mustafa II. (AE.SMST. II.) $27 / 2677$.

Başbakanlık Osmanlı Arşivleri, Ali Emiri Sultan Mustafa II. (AE.SMST. II.) $28 / 2753$.

Başbakanlık Osmanlı Arşivleri, Ali Emiri Sultan Mustafa II. (AE.SMST. II.) $32 / 3188$.

Başbakanlık Osmanlı Arşivleri, Ali Emiri Sultan Mustafa II. (AE.SMST. II.) $40 / 3914$.

Başbakanlık Osmanlı Arşivleri, Ali Emiri Sultan Mustafa II. (AE.SMST. II.) $59 / 6140$.

Başbakanlık Osmanlı Arşivleri, Bab-1 Defteri Baş Muhasebe Kalemi Matbah-1 Amire Eminliği (D.BŞM.MTE) 10694. BOA, Bab-1 Defteri Baş Muhasebe Kalemi Matbah-1 Amire Eminliği (D.BŞM.MTE) 11059.

Başbakanlık Osmanlı Arşivleri, Cevdet Hariciye (C.HR.) 134/6698.

Başbakanlık Osmanlı Arşivleri, Divan-1 Hümayun Sicilleri Name-i Hümayun Defteri (A.DVNS. NMH.d.), 5.

Başbakanlık Osmanlı Arşivleri, İbnülemin Hariciye (IEE.HR.) 4/424. 
Busbecq, O. G. (2014). Türk mektupları. (Çev. D. Türkömer). İş Bankas1 Yayınları. (Orijinal yayın tarihi 1555-1560)

Can, M. (2019). Osmanlı diplomasisinde mihmandar geleneği. Akademik Bakuş Dergisi, 13(25), 267-285. https://dergipark.org.tr/en/download/ article-file/884360

Defterdar Sarı Mehmed Paşa. (1995). Zübde-i vekâyiât tahlil ve metin (1066-1116/1656-1704). (Haz. A. Özcan). Türk Tarih Kurumu Yayınları.

Düzbakar, Ö. (2009). XV-XVIII. yüzyıllarda Osmanlı Devleti'nde elçilik geleneği ve elçilerin iaşelerinin karşılanmasında Bursa'nın yeri. Uluslararası Sosyal Araştırmalar Dergisi, 2(6) 182-194. https://www. sosyalarastirmalar.com/articles/diplomatic-tradition-in-the-ottomanstate-in-15th18th-centuries-and-the-status-of-bursaregarding-theprovisioning-of-env.pdf

Gerlach, S. (2010). Türkiye günlü̆̈̈̈. Cilt 1. (Çev. T. Noyan). Kitap Yay1nevi. (Orijinal yayın tarihi 1573-1576)

Gündüz, T. (2008). Safevîler. İçinde Türkiye diyanet vakfi İslam ansiklopedisi (C. 35, s. 451-457). Türkiye Diyanet Vakf1 Yayınları.

Gündüz, T. (2015). Son klzılbaşş̧̧ İsmail, Yeditepe Yayınevi.

Hammer Purgstall, J. (1992). Büyük Osmanl tarihi (Cilt. 12). (Haz. M. Çevik). Üçdal Neşriyat.

İskender Bey Münşî-yi Türkmen ve Muhammed Yusuf Vâle-yi İsfahânî. (2019). Târih-i âlem-ârâ-yi Abbasî (Cilt 4). (Çev. A Genceli \& Haz. İ. Aka). Türk Tarih Kurumu Yayınları.

Korkut, H. (2003). Osmanlı sefaretnameleri hakkında yapılan araştırmalar, Türkiye Araştırmaları Literatür Dergisi, 1(2), 491-511. https:// www.scribd.com/document/397337961/Korkut-Hasan-Osmanli-Sefaretnameleri-Hakkinda-Yapilan-Arastirmalar-pdf

Kurtaran, U. (2019, Mart 18-20). Osmanlı-Iran ilişkileri ve defter emini Mehmed B. Şair Nahifi'nin Iran sefareti (1698-1699) [Tam metin]. Uluslararası Türkiye Vizyonu Kongresi, Adana, Türkiye. https://atif.sobiad.com/index.jsp?modul=makalegoruntule\&id=AW71QGVByZgeuuwf-pBt 
Kütükoğlu, B. (1994). Vekayi'nüvis makaleler. İstanbul Fetih Cemiyeti Yayınları.

Kütükoğlu, M. S. (1989). XVIII. yüzyılda fevkalade elçilerin ağırlanması. Türk Kültürü Araştırmaları Dergisi, 17(1-2), 199-231.

Kütükoğlu, M. S. (1994). Osmanlı belgelerinin dili. Kubbealtı Neşriyat.

Mercan, H. (1996). Teşrifâtî-zâde Mehmed Efendi'nin defter-i teşrifâtı (transkripsiyon ve değerlendirmesi) [Yayınlanmamış yüksek lisans tezi]. Erciyes Üniversitesi.

Ocak, A.Y. (2002). Osmanlı kaynaklarında ve modern Türk tarihçiliğinde Osmanl1-Safevî münasebetleri (XVI.-XVII. yüzyıllar). Belleten, 66(246), 503-516. https://belleten.gov.tr/tam-metin-pdf/3605/tur

Özcan, A. (2000). Anonim Osmanlı Tarihi. Türk Tarih Kurumu.

Özlü, Z. (2013). XIX. yüzyılın ilk yarısında 1stabl-1 âmirenin gelir ve giderleri ile ilgili bir değerlendirme. Bilig, 65, 259-284. http://bilig. yesevi.edu.tr/yonetim/icerik/makaleler/2415-published.pdf

Raşid, M. E. \& Çelebizâde, İ. A. E. (2013). Tarih-i Raşid ve zeyli (Cilt 1). (Haz. A. Özcan, Y. Uğur, B. Çakır, \& A. Z. İzgöre). Klasik Yayınları.

Sak, İ. (2009). 1136-1141 yılları arasında İstanbul'a gelen İran elçilerinin bazı masrafları. Selçuk Üniversitesi Fen-Edebiyat Fakültesi Dergisi, (16), 117-161. https://dergipark.org.tr/tr/download/article-file/151596

Selânikî, M. E. (1999). Tarih (Cilt I). (Haz. M. İpşirli). TTK Yayınları.

Sevinç. N. (2012). Osmanlı Devleti'ndeki Iran elçilerinin gelir ve giderleri (1696-1741) (Kayıt no. 293030) [Yüksek lisans tezi, Marmara Üniversitesi]. YÖK Tez Merkezi.

Şahin Allahverdi, R. (2019). İsmiyle yaşayanlar: Siyavuş Paşa ve vakıfları. İdeal Kültür Yayınları.

Teply, K. \& Baykal, B. S. (1969). Nemçe imparatorlarının İstanbul'a yolladığı elçi heyetleri ve bunların kültür tarihi bakımından önemli tarafları. Tarih Araştırmaları Dergisi, 12, 247-263. https://doi. org/10.1501/Tarar_0000000373

Topaktaş Üstüner, H. (2021). Bab-1 Ali'nin tayinat uygulamalarında Avusturya elçileri (18. Yüzyıl). Near East Historical Review, 11(2), 1-18. http://dx.doi.org/10.29228/nehrreview.49773 
Topaktaş, H. (2015). Osmanlı diplomasisinde "tayinat" sisteminin uygulanışı ve kaldırılışı (1794) üzerine bazı tespitler. Akademik Incelemeler Dergisi, 10(1), 31-49. https://doi.org/10.17550/aid.63168

Topal, M. (2001). Silahdar Fındıklı11 Mehmed Ağa - Nusretnâme tahlil metin (1106-1133/1695-1721) (Kayıt No. 102494) [Doktora tezi, Marmara Üniversitesi]. YÖK Tez Merkezi.

Turan, S. (1964). 1560 tarihinde Anadolu'da yiyecek maddeleri fiyatlar1n1 gösteren bir İran elçilik heyeti masraf defteri. Ankara Üniversitesi Dil ve Tarih-Coğrafya Fakültesi Dergisi, 22(3-4), 273-294. https:// doi.org/10.1501/Dtcfder_0000000417

Unat, F.R. (2008). Osmanl sefirleri ve sefaretnameleri. TTK Yayınları.

Uzunçarşı11, İ. H. (1988). Osmanlı devletinin merkez ve bahriye teşkilatı. TTK. 


\section{Ekler}

EK 1

Ebu 'Ima 'sum Han'in Edirne'de Ikameti Süresince Kendisine Ödenen Tayinat

\begin{tabular}{|c|c|c|c|c|c|c|c|}
\hline Ürün & $\begin{array}{l}1 \text { Günlük } \\
\text { ürün }\end{array}$ & $\begin{array}{l}60 \text { günlük } \\
\text { miktar }\end{array}$ & $\begin{array}{l}17 \\
\text { günlük } \\
\text { miktar }\end{array}$ & $\begin{array}{l}77 \text { günlük } \\
\text { miktar }\end{array}$ & $\begin{array}{l}60 \text { günlük } \\
\text { Tutar/ } \\
\text { Akçe }\end{array}$ & \begin{tabular}{|l|}
17 \\
Günlük \\
Tutar/ \\
Akçe \\
\end{tabular} & $\begin{array}{l}77 \text { günlük } \\
\text { Tutar/ } \\
\text { Akçe }\end{array}$ \\
\hline Ezr-i Filibe & 20 kile & 1200 & 340 & 1.540 & 204.000 & 54.400 & 258.400 \\
\hline Erz-i Misır & 10 kile & 600 & 170 & 770 & 114.000 & 30.600 & 144.600 \\
\hline Asel & 20 kiyye & 1200 & 340 & 1.540 & 28.800 & 8.160 & 36.960 \\
\hline Dakik-i Has & 120 kiyye & 7200 & 2040 & 9.240 & 43.200 & 12.240 & 55.440 \\
\hline $\begin{array}{l}\text { Revgan-1 } \\
\text { sade }\end{array}$ & 100 kiyye & 6.000 & 1.700 & 7.700 & 258.000 & 71.400 & 329.400 \\
\hline Nohud & $\begin{array}{l}12 \text { k1yye } \\
720\end{array}$ & & 204 & 924 & 5.760 & 1.428 & 7.188 \\
\hline Sirke & 18 kıyye & 1080 & 306 & 1.386 & 4.320 & 918 & 5.238 \\
\hline Soğan & 30 kıyye & 1800 & 510 & 2.310 & 5.400 & 1.530 & 6.930 \\
\hline Sebzevat & 70 kıyye & 4200 & 1190 & 5.390 & 12.600 & 3.570 & 16.170 \\
\hline Ab-1 limon & 16 kiyye & 960 & 272 & 1.232 & 17.280 & 4.352 & 21.632 \\
\hline \begin{tabular}{|l|} 
Şeker-i \\
gubâr (toz)
\end{tabular} & 70 kıyye & 4200 & 1190 & 5.390 & 420.000 & $107.100^{5}$ & $527.100^{6}$ \\
\hline Şeker-i kelle & 20 kıyye & 1200 & 340 & 1.540 & 180.000 & 51.000 & 231.000 \\
\hline Kahve & 6 kıyye & 360 & 102 & 462 & 64.800 & 16.524 & 81.324 \\
\hline Meyve-i taze & 40 k1yye & 2400 & 680 & 3.080 & 36.000 & 8.160 & 44.160 \\
\hline Şem'-i asel & 2 kiyye & 120 & 34 & 154 & 15.600 & 4.080 & 19.680 \\
\hline \begin{tabular}{|l|} 
Rişte-i \\
Penbe
\end{tabular} & 5 kıyye & 300 & 85 & 385 & 36.000 & 10.200 & 46.200 \\
\hline Tuz-1 Eflak & 40 kıyye & 2400 & 680 & 3.080 & 9.600 & 2.720 & 12.320 \\
\hline $\begin{array}{l}\text { Revgan-1 } \\
\text { penbe }\end{array}$ & 30 kıyye & 1800 & 510 & 2.310 & 54.000 & 12.750 & 66.750 \\
\hline Süd & 10 kıyye & 600 & 170 & 770 & 5.400 & 1.020 & 6.420 \\
\hline Tavuk & 60 aded & 3600 & 1020 & 4.620 & 72.000 & 20.400 & 92.400 \\
\hline Yumurta & 300 aded & 18000 & 5100 & 23.100 & 18.000 & 5.100 & 23.100 \\
\hline Yoğurt & 50 kiyye & 3000 & 850 & 3.850 & 45.000 & 6.375 & 51.375 \\
\hline
\end{tabular}

17 günlük toz şekerin tutarı $(17 * 90$ akçe*70 kıye= 107.100$)$ olması gerekirken, 10.700 olarak kayıtlıdır ve bu nedenle hesapların sonuçlarına yansıyan 96.390 akçelik bir fark oluşmaktadır.

6 Önceki notta yapılan hesabın farkı sonuca yansımıştır. 


\begin{tabular}{|c|c|c|c|c|c|c|c|}
\hline Badam & 12 kıyye & 720 & 204 & 924 & 32.400 & 8.976 & 41.376 \\
\hline Fülfül & $\begin{array}{l}450 \\
\text { dirhem }^{7}\end{array}$ & $\begin{array}{l}27000 / 67,5 \\
\text { kiyye }\end{array}$ & \begin{tabular}{|l|}
19 kıyye \\
50 \\
dirhem
\end{tabular} & \begin{tabular}{|l|}
2750 \\
dirhem/86,5 \\
k1yye
\end{tabular} & 12.150 & 3213 & 15.363 \\
\hline Kimyon & $\begin{array}{l}450 \\
\text { dirhem }\end{array}$ & $\begin{array}{l}27000 / 67,5 \\
\text { kiyye }\end{array}$ & $\begin{array}{l}19 \text { kiyye } \\
50 \\
\text { dirhem }\end{array}$ & 900 & 2.025 & 572 & 2.597 \\
\hline Za'feran & 60 dirhem & 3600 & 1020 & 4.620 & 21.600 & 6.120 & 27.720 \\
\hline Darçın & $\begin{array}{l}360 \\
\text { dirhem }\end{array}$ & 21600 & 6120 & 27.720 & 129.600 & 15.300 & 144.900 \\
\hline Karanfil & \begin{tabular}{|l|}
120 \\
dirhem
\end{tabular} & 7200 & 2040 & 9.240 & 43.200 & 5.100 & 48.300 \\
\hline Peynir & 20 Kiyye & 1200 & 340 & 1.540 & 21.600 & 4.590 & 26.190 \\
\hline Nişasta & 6 kıyye & 360 & 102 & 462 & 5.760 & 1.224 & 6.984 \\
\hline$\ldots^{8}$ & $\begin{array}{l}160 \\
\text { dirhem }\end{array}$ & 7800 & 2210 & 10.010 & 23.400 & 6.630 & 30.030 \\
\hline Çörek otu & 2 kıyye & 120 & 34 & 154 & 3.600 & 1.020 & 4.620 \\
\hline Kakule & $\begin{array}{l}120 \\
\text { dirhem }\end{array}$ & 720 & 2040 & 2.760 & 2.160 & 6.120 & 8.280 \\
\hline Zencefil & $\begin{array}{l}150 \\
\text { dirhem }\end{array}$ & $\begin{array}{l}9.000 / 22,5 \\
\text { kiyye }\end{array}$ & $\begin{array}{l}2.550 \\
\text { dirhem } \\
6,150 \\
\text { kiyye } \\
\end{array}$ & $\begin{array}{l}11.550 \\
\text { dirhem } \\
28,650 \\
\text { k1yye }\end{array}$ & 2.700 & 765 & 3.465 \\
\hline Bekmez & 6 kıyye & 360 & 102 & 462 & 5.040 & 1.224 & 6.264 \\
\hline Ceviziçi & 1 kıyye & 60 & 17 & 77 & 1.200 & 340 & 1.540 \\
\hline Summâk ? ${ }^{9}$ & 6 kiyye & 360 & 102 & 462 & 28.800 & 8.160 & 36.960 \\
\hline \begin{tabular}{|l|}
$\begin{array}{l}\text { Sabun-1 } \\
\text { İzmir }\end{array}$ \\
\end{tabular} & 3 kıyye & 180 & 51 & 231 & 7.200 & 1.989 & 9.189 \\
\hline Çırâ & 30 kıyye & 1800 & 510 & 2.310 & 5.400 & 1.530 & 6.930 \\
\hline \begin{tabular}{|l} 
Paçavralık \\
$\ldots$ bezi $^{10}$ \\
\end{tabular} & $30 / 20$ top & 30 & 20 & 50 & 3.600 & 2.400 & 6.000 \\
\hline$\ldots$ & $\begin{array}{l}30 / 20 \\
\text { kiyye }\end{array}$ & 1800 & 510 & 2.310 & 18.000 & 5.100 & 23.100 \\
\hline Ab-1 verd & 2 kıyye & 120 & 34 & 154 & 7.200 & 2.040 & 9.240 \\
\hline Nân & $\begin{array}{l}230 \\
\text { k1yye/500 } \\
\text { ceift }\end{array}$ & 30000 & 8500 & 38.500 & 45.000 & 12.750 & 57.750 \\
\hline
\end{tabular}

Günlük istihkak dirhem cinsinden verilmiş ancak hesaplar vukiyye üzerinden yapılmıştır. (1 vukiyye $=400$ dirhemdir).

8 Okunamayan ürün isimlerinin yerine “..." üç nokta; okunuşundan emin olunamayan ürün isimleri içinse "?" soru işareti konulmuştur.

9 Defterde "Sat" harfiyle yazılmış ancak sözlüklerde "Sat"la yazıllışı yolmayıp, "sin" harfiye yazılmış hali ise "summâk"tır. Sumak olsa dahi elçiye kıyyesi 80 akçeden, günlük 6 kıyye sumak verilmesi abartılı görünmektedir.

10 Başka defterlerde "meşale için penbe bezi" varsa da buradaki kelime "penbe" değildir. 


\begin{tabular}{|c|c|c|c|c|c|c|c|}
\hline Misk & 9 kese & 540 & 153 & 693 & 9.720 & 2.754 & 12.474 \\
\hline$\hat{U d}$ & 30 dirhem & 1800 & 510 & 2.310 & 72.000 & 20.400 & 92.400 \\
\hline Anber & 1 dirhem & 60 & 17 & 77 & 30.000 & 8.500 & 38.500 \\
\hline \begin{tabular}{|l|} 
Seker-i \\
nebât
\end{tabular} & 10 kıyye & 600 & 170 & 770 & 108.000 & 30.600 & 138.600 \\
\hline Çay ve ... & 100 & 6000 & 1700 & 7.700 & 18.000 & 5.100 & 23.100 \\
\hline Kaymak & 7 kıyye & 420 & 119 & 539 & 25.200 & 7.140 & 32.340 \\
\hline $\begin{array}{l}\text { Mastaki } \\
\text { (Mastika) }\end{array}$ & 20 dirhem & 1200 & 340 & 1.540 & 3.600 & 1.020 & 4.620 \\
\hline Turşhâ-y1 ... & 7 kıyye & 420 & 119 & 539 & 12.600 & 3.570 & 16.170 \\
\hline Kişniş mor? & 10 kıyye & 600 & 170 & 770 & 24.000 & 4.080 & 28.080 \\
\hline \begin{tabular}{|l|} 
Ades \\
(mercimek)
\end{tabular} & 3 kıyye & 180 & 51 & 231 & 1.440 & 306 & 1.746 \\
\hline ... Şam & 2 k1yye & 120 & 34 & 154 & 7.200 & 1.632 & 8.832 \\
\hline Fındık içi & 6 kıyye & 360 & 102 & 462 & 10.800 & 1.836 & 12.636 \\
\hline \multicolumn{6}{|c|}{ Ayva? çekirdeği ve ba'z1... ve ba'zı ma'adin?... } & 3.000 & 3.000 \\
\hline \multicolumn{6}{|c|}{ Sacayağ 1 ve ahen kürek ve maşa } & 900 & 900 \\
\hline YEKÜN & & & & Sonuç & 2.393 .955 & 620.028 & 3.013.983 \\
\hline- & & & & Defterde & 2.413.395 & 523.638 & \\
\hline - & & & & Fark & 19.440 & 96.390 & \\
\hline
\end{tabular}

Not. Başbakanlık Osmanlı Arşivleri, Cevdet Hariciye (C.HR.) 134/6698. 